\title{
The EU Digital Single Market from a Consumer Standpoint : How Do Promises Meet Means?
}

\section{Havu, Katri Annikki}

2017

Havu, K A 2017 , ' The EU Digital Single Market from a Consumer Standpoint : How Do

Promises Meet Means? ' , Contemporary Readings in Law and Social Justice , vol. 9 , no. 2 ,

pÿpp. 146183 . https://doi.org/10.22381/CRLSJ9220179

http://hdl.handle.net/10138/243249

https://doi.org/10.22381/CRLSJ9220179

unspecified

publishedVersion

Downloaded from Helda, University of Helsinki institutional repository.

This is an electronic reprint of the original article.

This reprint may differ from the original in pagination and typographic detail.

Please cite the original version. 


\title{
THE EU DIGITAL SINGLE M ARKET FROM A CONSUMER STANDPOINT: HOW DO PROMISES MEET MEANS?
}

\author{
KATRI HAVU \\ katri.havu@helsinki.fi \\ Faculty of Law, \\ University of Helsinki
}

\begin{abstract}
This article discusses the EU Digital Single Market Strategy, focusing on implications for consumers. The emphasis is on the position of consumers in terms of consumer protection and competition issues. The study analyses the goals set for the Digital Single Market, and how consumer-related aims are discussed in official documents, and mirrors the expressed aims as well as concerns with concrete legislative proposals and action taken, in particular, by the European Commission. The main methods used are based on theoretical legal dogmatics and philosophy of law. The analysis illustrates that some of the highlighted concerns and measures appear overemphasized in terms of their practical significance. Moreover, the measures contemplated and taken do not seem to fully remedy the problems underlined by Digital Single Market materials, or remedying is only beginning. Even though the rhetoric emphasizes how much the Digital Single Market Strategy benefits consumers, the goals related to the position of consumers, and steps for achieving these goals, appear at points vague in official documents. For instance, boosting "consumer confidence" or "trust" is underlined as a goal but not fully mirrored by concrete action or analysis.
\end{abstract}

Keywords: EU law; EU Digital Single Market; consumers; e-commerce; digital content; harmonization; justification and reasoning; competition; collaborative economy

How to cite: Havu, Katri (2017). "The EU Digital Single Market from a Consumer Standpoint: How Do Promises Meet Means?," Contemporary Readings in Law and Social Justice 9(2): 146-183.

Received 23 August $2017 \cdot$ Received in revised form 24 September 2017 Accepted 26 September $2017 \cdot$ Available online 19 October 2017

\section{Introduction}

The Digital Single Market ("DSM") is one of the most prominent current projects of the EU and the European legislator, in particular the European Commission ("Commission"). For European consumers, the DSM is great news: "In a Digital Single Market, there are fewer barriers, and more opportunities: it is a seamless 
area where people and business can trade, innovate and interact legally, safely, securely, and at an affordable cost, making their lives easier." The DSM is "one in which the free movement of goods, persons, services and capital is ensured and where individuals and businesses can seamlessly access and exercise online activities under conditions of fair competition, and a high level of consumer and personal data protection." Moreover, "(s)implified and modern rules for online and digital cross-border purchases will encourage more businesses to sell online across borders and increase consumer confidence in cross-border e-commerce," ${ }^{3}$ and "Europeans will soon be able to fully use their online subscriptions to films, sports events, e-books, video games or music services when travelling within the EU."

Nevertheless, these impressive promises and aims may raise the question whether everything the DSM seeks to deliver may be achieved as effectively and as soon as communicated. Furthermore, goals such as those listed above are actually contingent upon numerous complex legal issues which might not be resolved by relatively quickly-drafted legislation and few targeted competition investigations. Moreover, if the action taken is pointillist and only tackles some aspects of the challenges of e-commerce and online distribution, the remaining difficulties and divergences in applicable rules might undermine the benefits of action taken.

Even now, the intended pace for developing the legal framework and remedying potential problems appears somewhat challenging. The original DSM Strategy documents declared that sixteen more detailed initiatives would be published by the end of 2016. ${ }^{5}$ Of the relevant focus areas, some have (publicly) progressed only after 2016. Moreover, some of the promised "detailed initiatives" have only entailed relatively preliminary public documents. ${ }^{6}$

This article discusses the implications of the DSM Strategy from the standpoint of consumers. The emphasis is on consumer protection and competition issues as well as on the position of consumers from market and transaction perspectives. For example, privacy and data protection matters are mainly excluded from the scope of this analysis. The study analyses the goals of DSM, and how consumer-related aims are discussed in official documents, and mirrors the expressed aims as well as concerns with concrete legislative proposals and action taken, in particular, by the European Commission.

The goals of this study include critically discussing the focus and justification of legislative proposals and law enforcement in the context of the DSM Strategy. The observations presented in this article may contribute to assessing the quality and usefulness of initiatives under the DSM umbrella. Additionally, the findings of this study raise the question whether consumer-focused "rhetoric of aims" is partially misleading, for example promising more than the European legislator is delivering.

Many aspects discussed in this contribution could be explored further and in more detail. Nevertheless, the aim of this article is an overarching look at DSM initiatives, materials and different related aspects from the standpoint of rhetoric concerning improving the position of consumers. 
The following Sections address central DSM goals, plans, and measures affecting the position of consumers in terms of e-commerce in physical goods (Section 2), digital content (Section 3) and competition issues (Section 4). In the Discussion Section (5), analytical remarks are presented in terms of achieving goals and the concrete, practical effects of plans and measures. Finally, concluding remarks are presented in Section 6.

\section{E-Commerce in Physical Goods}

\subsection{Background, Central Concerns and Goals}

In December 2015, the Commission published a legislative proposal package concerning online consumer contracts for sales of physical goods (such as buying clothes online) and digital content (such as e-books, movies and TV shows). The directive proposals regarding tangible products and digital content are separate but closely related and highly similar. ${ }^{7}$ The underlying idea behind the proposal package is that divergent European rules on key aspects of consumer contracts slow down the development of e-commerce, as consumers may be insecure about their rights to a degree that results in abstaining from transactions with foreign companies, and as online sellers currently have to modify their contracts and practices to comply with the laws of other EU Member States in order to sell outside their own country. ${ }^{8}$

The consumer contracts proposal package notes that, regardless of the partial harmonization of consumer law in the EU, some central aspects of consumer transactions are still subject to divergent national rules. Hence the proposals tackle and fully harmonize "in a targeted way the key mandatory rights and obligations of the parties to a contract for the supply of digital content and the online sales of goods," focusing on matters such as conformity with the contract, hierarchy and exercise of remedies, and the consumer's right to terminate the contract. ${ }^{10}$ The directive proposals include similarities with the existing Consumer Sales Directive (EC) $1999 / 44,{ }^{11}$ transforming some of its rules into fully harmonized ones.

Developing consumer contract rules in this manner will, according to the Commission, reduce costs resulting from differences in contract law, improve legal certainty for businesses, and boost consumer confidence or trust. ${ }^{12}$ In particular, the last-mentioned aspect is strongly emphasized in the documents. ${ }^{13}$ Moreover, the proposal documents note that lifting the barriers related to contract law would bring significant macro-economic benefits. ${ }^{14}$

As for online sales of physical goods in particular, the materials note that the proposed key consumer contract rules will eliminate some existing legal fragmentation between Member States. Earlier EU harmonization on the notion of conformity with the contract and as regards remedies in the case of non-conforming goods has been minimum harmonization, so that divergences currently exist between national solutions. ${ }^{15}$ The proposals are also supposed to raise the overall level of consumer protection in the EU. As to e-commerce in physical goods, this is particularly relevant in the case of defects and as regards extending the period for 
reversing the burden of proof (over the issue whether goods were non-conforming when delivered $)^{16}$ to two years, aligning it with a two-year legal guarantee period. ${ }^{17}$ The proposed rules will thus "empower consumers to buy online cross-border and also make it easier for them to exercise their rights." ${ }^{18}$ Moreover, the Commission notes that the legal developments mentioned could also contribute to producing higher quality and more durable goods. ${ }^{19}$

The Commission explains that the proposed online sales rules supplement EU law on consumer rights ${ }^{20}$ and on e-commerce and electronic contracts. ${ }^{21}$ Regulation of unfair contract terms would remain unaffected. ${ }^{22}$ The proposed rules are considered as apt to remedy the most central remaining divergences between Member State laws in terms of mandatory consumer contract rules in e-commerce. ${ }^{23}$ The proposed consumer contract rules for e-commerce in goods should, according to the Commission, be seen as part of the entire DSM program, and the proposal will be executed together with other plans which relate, for example, to the role of platforms, parcel delivery, consumer law enforcement and dispute resolution. ${ }^{24}$

Furthermore, the proposal materials state that rules for online and offline sales of goods should be aligned and that the aim is one coherent set of consumer sales rules to apply to both online and offline transactions across the Union. The online sales rules and other EU consumer law are developed in parallel since the Commission's REFIT exercise, ${ }^{25}$ which examines and seeks to develop existing consumer law, is ongoing simultaneously with the DSM project. ${ }^{26}$

As regards concerns and goals related to competition issues and potential competition restrictions, as well as geo-blocking, these are discussed in Section 4.

\subsection{Plans and Measures in a Nutshell}

The proposed directive containing consumer contract rules for e-commerce in goods entails full harmonization of certain key rules, in particular regarding conformity, remedies and modalities for the exercise of remedies. ${ }^{27}$

To summarize the key contents of the proposed rules, Articles 4-8 focus on conformity with the contract as well as on the relevant time (generally that of passing of risk, when the consumer obtains control over the goods) and the burden of proof in establishing conformity or non-conformity with the contract. ${ }^{28}$

Proposed Article 9 sets out consumer remedies for lack of conformity with the contract as well as the order for the exercise of remedies. As a first step, the consumer should be entitled to have the goods repaired or replaced; in a second step the consumer should be entitled to a price reduction or to terminate the contract (where lack of conformity is not or cannot be remedied through repair or replacement). The consumer would have the right to withhold performance until the goods are brought into conformity. ${ }^{29}$ Proposed Articles 10-13 set out rules on some further details related to remedies, and Article 14 notes that the consumer should be entitled to a remedy for lack of conformity which becomes apparent within two years as from the relevant time for establishing conformity - national limitation periods would be unable to shorten this time frame. ${ }^{30}$ 
Proposed Article 15 sets transparency requirements as to commercial guarantees issued by sellers. The Article adds that a guarantee is binding on the seller in accordance with the conditions contained in advertisements, pre-contractual information and in the guarantee statement. In the case of inconsistencies between sources of conditions, those more advantageous to consumers should prevail. Article 16 entitles the seller to redress in case of an act or omission by a person in earlier links in the chain of transactions which triggered the seller's liability to the consumer for lack of conformity. ${ }^{31}$

The DSM project also covers, for instance, initiatives related to the role of platforms,${ }^{32}$ parcel delivery (a proposal addressing affordability and availability of cross-border parcel delivery and returns was adopted in 2016), ${ }^{33}$ and to enforcement of consumer law as well as consumer dispute resolution and redress. In the proposed directive containing consumer contract rules for e-commerce in goods, the Commission in particular highlights the entry into operation of the Online Dispute Resolution platform ${ }^{34}$ and review of the Consumer Protection Cooperation Regulation (EC) 2006/2004. ${ }^{35,36}$ The Commission adds that "fully harmonized contract law rules in the EU will also facilitate coordinated enforcement actions" by co-operating consumer protection authorities. ${ }^{37}$ Enforcement, dispute resolution and redress issues will be discussed further in Section 5.

Moreover, the Commission has issued new guidance on applying the Unfair Commercial Practices Directive (EC) 2005/29, ${ }^{38}$ with a view to challenges in the online environment. ${ }^{39}$

Comprehensively analyzing the role of platforms is a significant aspect of the original DSM Agenda. Online platforms are major players both in e-commerce in physical goods and distribution of digital content, and in posing novel legal challenges. In 2016, the Commission published a Communication and related documents concerning opportunities and challenges pertaining to online platforms, but concrete proposals and measures are mainly only to be seen in the future. ${ }^{40}$ Issues related to platforms will be discussed further in Sections 4 and 5.

As regards functioning competition and potential competition concerns as well as geo-blocking, plans and measures will be discussed in Section 4.

\section{Digital Content}

\subsection{Background, Central Concerns and Goals}

As regards consumer contracts, the overarching rationale of online consumer contracts proposals has already been discussed above in the context of e-commerce in physical goods. Aspects such as diverging legislation hindering easy cross-border commerce, the resulting narrower range of supply, and lack of "consumer confidence" are relevant in the context of digital content as well as in the case of goods. ${ }^{41}$ Moreover, as regards consumer contracts for digital content in particular, the proposal documents underline that consumers suffer detriment due to lack of clear contractual rights, for instance in the case of faulty content, and suggest that 
filling the most obvious gaps in current EU law in terms of consumer contracts will facilitate and encourage cross-border digital-content commerce. ${ }^{42}$

In terms of the relationship between the proposed rules on digital-content contracts and earlier EU consumer law, the Commission comments on the relationship in much the same way as in the proposal for physical goods contracts. ${ }^{43}$ Again, it is noted that other DSM and consumer law initiatives complement the digital-content contracts proposal. The Commission in particular highlights ongoing projects and revisions which concern cross-border portability of digital content, the position of platforms, and consumer law enforcement or redress. ${ }^{44}$ It is also noted that the proposal is consistent with and complemented by existing EU law regimes regarding copyright and data protection. ${ }^{45}$

As for portability, the goal has been to increase the accessibility of purchased or subscribed online content for consumers when travelling outside their own Member State. Traditionally, online content services and products available and purchased in one Member State may have been inaccessible outside that country. ${ }^{46}$

Concerns related to competition issues and geo-blocking are discussed in Section 4.

\subsection{Plans and Measures in a Nutshell}

The most central aspects of the proposal on contracts for the supply of digital content are as follows: Article 1 sets out the subject matter of the proposed directive and Article 2 includes definitions of central concepts. Article 3 further defines the scope of the proposed directive and Article 4 notes the full-harmonization nature of the document.

Articles 5-10 discuss supply of digital content and conformity with the contract. As a main rule, digital content should be supplied instantly (Article 5). Digital content supplied over a period of time must be in conformity with the contract throughout the duration of the contract and the version of digital content supplied to the consumer must also be the most recent version available at the time of concluding the contract (Article 6). Moreover, lack of conformity of digital content resulting from incorrect integration into the consumer's hardware and software should amount to lack of conformity of the digital content itself if the reasons for incorrect integration are related to the supplier (Article 7). Digital content must be clear of third-party rights, including intellectual property rights (Article 8). The burden of proof of absence of lack of conformity is on the supplier, unless the consumer's digital environment is not compatible with the digital content; this reversal of the burden of proof is not limited in time (Article 9). The supplier is liable to the consumer if the content fails to conform with the contract or if content was not supplied at all (Article 10). ${ }^{47}$

Articles 11-16 discuss remedies and their order of use. Crucially, the consumer can terminate the contract immediately if the supplier fails to supply the digital content altogether (Article 11). ${ }^{48}$ Article 17 provides the supplier with a right of redress in the contractual chain in the case of liability to the consumer. 
As regards portability of purchased or subscribed digital content, a proposed regulation was issued at an early stage of the DSM project. ${ }^{49}$ The final rules have been agreed on and the actual Regulation, published in the summer of 2017, will become applicable in March 2018..$^{50}$

The Commission's new guidance concerning the Unfair Commercial Practices Directive (EC) 2005/29 is also relevant for distribution of digital content. ${ }^{51}$ Platform matters, which were briefly mentioned above in Section 2.2., will be discussed further in Sections 4 and 5. Enforcement, dispute-resolution and related issues are discussed in Section 5. As regards functioning competition and possible competition concerns, as well as geo-blocking, plans and measures taken will be discussed in Section 4.

\section{Competition Issues}

\subsection{Background, Central Concerns and Goals}

The DSM materials underline the necessity of functioning competition as regards digital markets. With respect to implications for consumers, they note, crucially, that businesses create some barriers to accessing goods and services online across borders - barriers which could be anticompetitive. Competition law enforcement might thus help in creating better access, broader choice and lower prices for consumers. ${ }^{52}$ Central competition concerns mentioned in the DSM materials cover unjustified geo-blocking (referring to both digital content distribution and ecommerce in physical goods), the market power of some online platforms, and competition in the telecoms sector. ${ }^{53}$

Online business models, sales and distribution may be said to require a remarkable rethinking, adapting and developing of EU competition law and its established interpretations. Practices and strategies of companies are changing due to the development of digitalization. New competition issues are arising, while some existing issues may surface in novel contexts and become more complex or central than before, for instance, as regards vertical agreements or applying prohibition of abuse of dominance.

The online environment and its new possibilities may, for example, encourage supplier companies to analyze whether they should more actively engage in distribution and retail themselves, whether closed selective distribution systems would be useful, and what the policy should be on selling products to consumers via general, independent online marketplaces such as Amazon or eBay. ${ }^{54}$ Moreover, accessibility and increased transparency of pricing information facilitates observing, comparing, adjusting and monitoring prices, which in turn affects multiple market actors and their strategies. Development may also overemphasize price competition at the cost of product quality and innovation. ${ }^{55}$ Furthermore, common sales platforms facilitate technical measures to make competitors' prices uniform. ${ }^{56}$

Contemporary possibilities to gather and analyze significant amounts of sales data also "point to possible competition concerns," for instance as regards infor- 
mation exchange between companies that compete in some markets while having other kinds of interrelationship with respect to other markets. ${ }^{57}$ Additionally, for example, products, services and business models with digital content bring forth novel issues of the interface between copyright, competition and Internal Market free movement law. ${ }^{58}$

Applying current EU competition provisions to cases involving the online environment may be challenging and the end results unpredictable. ${ }^{59}$ There are numerous online business-related details where the significance of EU competition law is still to be established or explained by the EU Courts, possibly together with the Commission and the European legislator.

The applicability and outer limits of Article 101 of the Treaty on the Functioning of the EU ("TFEU") is a general theme which is constantly relevant in the online environment. The prohibition forbids competition-restricting agreements and the like between undertakings, and the issue of whether there is an anticompetitive agreement or the like may be ambiguous in the online business context. If no such arrangement is found, the practice under scrutiny may not be tackled by means of Article 101 TFEU. ${ }^{60}$ Hence, new online-context interpretations of matters such as agency relationships, competition-restricting vertical agreements and the outer limits of anticompetitive cooperation are needed in order to apply EU competition law to real-life cases.

For instance, the factual setting of the Eturas case could be seen as raising several issues related to online platforms and online sales, even though the preliminary ruling questions presented to the Court of Justice of the EU ("CJEU") in essence focused on the presence of concerted practices (as to consumer discounts) between travel agency companies selling bookings through a common sales platform. $^{61}$

In the pending case of Coty, a central issue is competition law evaluation from the standpoint of Article 101 TFEU and the general vertical agreement Block Exemption Regulation (EU) 330/2010 ${ }^{62}$ in the context of a selective distribution system for luxury goods which primarily serves to protect the "luxury image" of the goods and where members of the selective distribution system operating at the retail level are generally prohibited from engaging third-party undertakings discernible to the public to handle online sales. ${ }^{63}$ The question is whether an online marketplace ban preventing sales via third-party general platforms such as Amazon should be seen as justified in the context of protecting the brand image, and how the ban compares to other, acceptable and unacceptable, limitations set for retailers. The case is one example of the need for new "online interpretations" and is expected to clarify the applicability of guidance presented in earlier cases. ${ }^{64}$ From the standpoint of consumers, resolving issues of extensive online distribution is of practical relevance, as these issues affect how and from whom their favorite products may be purchased and, through price competition, prices. Access to major platforms may also, from the retailer/distributor perspective, be decisive for reaching big customer groups, as platforms provide the infrastructure needed and facilitate 
visibility and payment options - matters that are of relevance for newer and smaller manufacturers, in particular. This translates, again, into implications for consumer choice as well as for competition related to price, quality and innovation. ${ }^{65}$

As regards Article 102 TFEU, prohibition of abuse of a dominant market position, applying this provision to potentially problematic situations of online context might not be simple, either. For instance, market definitions and finding dominance might constitute intricate matters in the context of e-commerce and rapidly changing markets. Further, for example, the issue of refusing to supply consumers (from certain countries, as in geo-blocking) is complex, while earlier CJEU guidance on applying EU competition law may not necessarily be directly applicable, as it has focused on refusal to supply companies. Similarly, evaluating price discrimination may be challenging. ${ }^{66}$

\subsection{Plans and Measures in a Nutshell}

When launching the DSM project, the Commission highlighted initiating a competition sector inquiry focusing on application of competition law in the e-commerce area. The sector inquiry was also noted as potentially leading to targeted competition investigations. ${ }^{67}$ Moreover, the Commission reported plans to make legislative proposals in the first half of 2016 to end unjustified geo-blocking. ${ }^{68}$ Further, the Commission announced that before the end of 2015 it would launch a comprehensive assessment of the role of platforms, including in the sharing economy, and of online intermediaries, covering issues such as transparency in search results, how platforms use the information they collect, relations between platforms and suppliers, and constraints on the ability of individuals and businesses to move from one platform to another ${ }^{69}$ A proposal for overhaul of the telecoms regulatory framework was also to be expected in $2016 .^{70}$

In May 2016 the Commission issued a proposal on unjustified geo-blocking; ${ }^{71}$ draft legislation is currently being negotiated between the EU legislative bodies to reach agreement on the final text. ${ }^{72}$ The proposal is meant to prevent the problem that customers are unable to buy goods and services from traders located in a different Member State and to prevent nationality- or location-related discrimination in prices and sales conditions. In particular, the emphasis is on ceasing unjustified geo-blocking, which is rooted in the desire to segment markets along national borders. This kind of geo-blocking is problematic from the perspective of EU Internal Market and competition law, but also unjustly reducing choice and for instance price competition when viewed from the consumer perspective. ${ }^{73}$ Additionally, the e-commerce sector inquiry results discussed below entailed some preliminary findings related to geo-blocking practices.

As regards prohibiting discrimination, apparently the forthcoming geo-blocking legislation does not immediately fully cover electronically-supplied services such as cloud services because the Commission proposed delaying application of the relevant provision until mid-2018. Moreover, the non-discrimination provision will 
probably not fully cover non-audio-visual digital content services concerning copyright protected works, even though later extension will be possible. ${ }^{74}$

Continuing in terms of actual action taken, the final results of the e-commerce sector inquiry were published in May $2017 .{ }^{75}$ The key findings on competition concerns include the remark that the possibilities of online commerce have remarkably changed the distribution and sales strategies of companies, and thus competition. For instance, significant potential contractual restrictions exist in distribution. New practices may unduly prevent consumers from benefiting from greater product choice and lower prices, thereby warranting Commission action. Moreover, potentially problematic contract practices are in place as regards digital content distribution, but any intervention must carefully consider licensing and copyright issues in addition to competition law. ${ }^{76}$

Additionally, some companies have reportedly voluntarily changed their ecommerce practices during or due to the sector inquiry. ${ }^{77}$ Moreover, in February 2017 the Commission communicated that new investigations have been opened into holiday accommodation, PC video game distribution and consumer electronics pricing practices that may limit competition ${ }^{78}$ and, more recently, regarding practices by Nike, Universal Studios and Sanrio in the context of online distribution of licensed merchandise. ${ }^{79}$ Further, in June 2017, the Commission found that Google had abused its dominant market position as a search engine by giving an advantage to another Google product, its comparison shopping service, in the search results it produced. ${ }^{80}$

The platform-related documents published by the Commission in 2016 are relatively preliminary and mostly present vague ideas and approaches or "principles" for future studies and proposals. ${ }^{81}$ In its Platforms Communication, the Commission identifies as relevant target areas, inter alia, B2B relations between platforms and other (supplier) businesses, together with platform-related competition issues. ${ }^{82}$ These may have direct and indirect implications for consumers as well, but remedying potential problems, such as B2B unfair contract clauses and questionable trading practices, is expected to be discussed in more detail only at the end of $2017 .{ }^{83}$ However, competition investigations and decisions based on them can be done and are even taking place, although the number of cases resolved or pending is not yet very high.

For example, the Commission accepted commitments in the Amazon e-books case that concerned Amazon's potential abuse of a dominant market position (Article 102 TFEU) and in particular clauses in e-book distribution agreements (so-called MFN or parity clauses ${ }^{84}$ requiring publishers to offer Amazon similar or better terms than those offered to its competitors, and/or to inform Amazon about more favorable or alternative terms given to competitors). According to the Commission, the clauses may have made it more challenging for other e-book platforms to compete by reducing publishers' and competitors' ability and incentives to develop new e-books and alternative distribution modes. Thus, the clauses may have led to 
less choice, less innovation and higher prices for consumers due to less overall competition in e-book distribution. ${ }^{85}$

As for competition in the field of telecommunications (and more general issues of roaming and availability of the Internet) several proposals and measures have occurred in 2016-2017. ${ }^{86}$

\section{Discussion}

\subsection{Full Harmonization, Targeted Aspects - and Other Issues Regarding Consumer Contracts}

\section{EU Harmonization of Targeted Aspects of Consumer Contracts}

With respect to proposals for consumer contract rules, the choice of instrument, a directive, allows national legislators to draft and incorporate the required rules in the best possible way from the standpoint of the national system. A directive is a means of "less intervention" than an EU regulation - as the Commission highlights. However, the proposed directives on contracts for digital content and e-commerce in goods aim at full harmonization of certain aspects of consumer contract rules, in these particular contexts. Using directives may be perceived as partially contradictory to the full harmonization goal. The justifications and discussion by the Commission are interesting and partially counter-intuitive in this respect, as the Commission appraises the possibility of different solutions in Member States while emphasizing problems caused by diverging legal regimes. ${ }^{87}$ The combination of a directive as an instrument, full harmonization, and a targeted or pointillist selection of issues has already spurred critical comments. ${ }^{88}$

Full harmonization is a solution for situations where a truly level playing field is the goal: Member State laws may not be more permissive or more stringent than EU legislation prescribes. Nonetheless, the process of implementing, interpreting and applying an EU directive and directive-based rules, and combining them with law of national background, is inherently resulting in diverging case outcomes, not fully harmonized ones. National law and traditions surrounding directive-based rules have direct and indirect implications for individual cases. This is true, in particular, as regards open-ended or vague directive provisions, but is also of relevance more generally. ${ }^{89}$

Previously, the European legislator has used methods of both minimum and full (or maximum) harmonization in the sphere of consumer law. Starting from 2002, it was highlighted, in parallel with the goal of making the EU "the most competitive economy," that full harmonization was the new objective of EU legislation in the field of consumer contract law and commercial practices. Crucially, full harmonization was (as it still visibly is) aimed at striking down barriers for the growth of business and at enhancing cross-border commerce. ${ }^{90}$ A comprehensive Consumer Rights Directive Proposal of $2008,{ }^{91}$ which was supposed to combine the areas of several earlier pieces of legislation as well as include novel aspects, illustrated the 
new approach. However, it was vigorously criticized by commentators, regarding, inter alia, whether the proposed rules could resolve the problems cited as justification for the proposal, whether the chosen level of consumer protection was appropriate, and whether full harmonization was any better than less interventionist options. ${ }^{92}$ Later, a much less comprehensive Directive was adopted, ${ }^{93}$ but full harmonization was nevertheless used in that Directive, as it had been in some other areas. ${ }^{94}$ Now, the concept of "targeted full harmonization" appears to have become a staple in Commission plans. ${ }^{95}$

As regards the proposed directives for online consumer contract rules, several issues should be noted on the rhetoric and justifications from the Commission and on how the proposals themselves appear to match the express consumer-related goals of the DSM Strategy. To start with, close examination suggests that the most strongly-emphasized goal of the proposed directives is enhancing growth and facilitating cross-border commerce for companies. This also seems to hold true for some other DSM initiatives. Even though the position of the consumer, consumer rights and consumer confidence are highlighted, the documents strongly underline the need to eliminate obstacles to cross-border commerce with the rationale of making business easier. ${ }^{96}$ This has indirect positive implications for consumers, as well, for example in the form of increased choice of products and more effective price competition. Moreover, business and growth-centered goals do not, as such, mean that consumer protection and promotion of consumer rights are irrelevant: those matters may also be pursued.

However, the possible main emphasis on promoting growth and facilitating sales for businesses may explain some other issues related to the proposals, such as the general, ambitious-looking aims but relatively vague discussions concerning goals and measures for improving the situation of consumers, and the slight mismatch between the expressed aims and the "narrow," specific rules proposed. Further, the somewhat problematic goal of boosting consumer confidence might even be more rhetoric than something to be taken too seriously (see also Section 5.3.). If improving the position of consumers is seen as secondary (but necessary in order to best "sell" the proposals), that explains these elements, even though it does not justify them.

Optimal choices regarding harmonization and divergence may actually vary depending on the primary goals of the contemplated legislation. For a smooth, level Internal or Single Market, with minimal barriers to cross-border commerce, EUlevel legislation and fixed rules may easily be seen as the best option, instead of allowing room for variation between the Member States. Nevertheless, as regards consumer protection and consumer rights, the matter can be said to be more complex. For instance, different consumer law rules and levels of protection in different countries could be seen as reflecting different preferences. Choosing a "correct standard" of protection (and especially a fully binding one) for all EU Member States may thus be challenging. Further, which is the correct system level for issuing consumer protection legislation may be seen as debatable. ${ }^{97}$ 
The Commission highlights that the consumer contract proposals allow consumers across the Union to enjoy a "high level of consumer protection." However, the proposals do not elevate the level of consumer protection for all Member States. ${ }^{98}$ For instance Nordic countries have previously opposed EU harmonization due to the high level of consumer protection they wish to maintain. ${ }^{99}$

Nonetheless, EU legislation (or even more global transnational legislation) is conceivably a more suitable option for unifying markets and thus, for instance, for increasing suppliers, competition and consumer choice. Carefully comparing these potential benefits to the possible shortcomings or problems of fully harmonized (pointillist) European consumer law rules should constitute part of the justification for legislative proposals. The Commission materials illustrate that this type of consideration has indeed taken place to some extent. ${ }^{100}$ However, more elaborate, more express discussions, which would consider in detail issues such as consumer protection preferences and possible intricacies as regards "abandoning" them, would also be welcome.

What should also be noted is that legislation-based barriers currently preventing a unified and complete European DSM are not rooted in the consumer contract law field alone. Thus, harmonizing consumer contract rules, or some of them, does not make EU-wide e-commerce suddenly extremely easy and hindrance-free. For instance, the DSM platform materials note the problem of divergence between Member States with respect to several kinds of rules applicable to online platforms, such as regarding B2B relationships, and the resulting market fragmentation. ${ }^{101}$

As regards the practical effects of the consumer contract rules proposed, it is evident that issues of the interface between EU and national law and interpreting EU law-based rules deserve attention. If a "fully harmonized" rule is too vague, and/or too "narrow" (targeted), the practical effects of EU legislation might not be those contemplated by the European legislator. Whether the proposed directives are too pointillist, entailing individual specific norms but not forming a functioning whole, and leave too much for the national laws of Member States is highly relevant. At least at this stage it appears that achieving a level playing field without barriers related to differences in applicable laws is not possible by means of the current proposals.

In terms of details of the rules proposed, the effect of Articles 1, 3 and 4 of the proposed directive on digital content and Articles 1 and 3 of the directive on goods is to establish full harmonization of rules provided in the directives. Furthermore, those Articles signify that Member States may keep in force rules and legislate on aspects not (exhaustively) regulated by the directives. This applies, for example, to "general contract laws such as rules on formation, the validity or effects of contracts, including the consequences of the termination of a contract." 102 Thus, relatively central aspects of consumer contracts are left for possibly diverging national contract law and the law of obligations. The proposed directives would not establish any coherent, uniform or self-sufficient EU law body of consumer contract rules for the online environment. 
The proposed rules discuss conformity with the contract and remedies in case of non-conformity in a relatively detailed manner. ${ }^{103}$ It should be noted that the consequences of termination are discussed as regards, in particular, restitution but that the proposed rules are neither exhaustive nor highly elaborate. ${ }^{104}$ Furthermore, other heavy reliance on national laws or potential for variation is also visible. For example, Article 14 of the proposed directive on goods, together with Article 9, signifies that Member State laws may contain diverging limitation periods for the use of remedies, while the directive provides only an "outer limit" for those periods. ${ }^{105}$ Article 14 of the proposed directive on digital content sets out a consumer's right to damages, ${ }^{106}$ but notes that national laws should provide more specific details. Further, Article 15 of the proposed directive on goods notes that Member States may lay down additional rules on commercial guarantees insofar as those rules do not reduce the protection set out in the Article.

Article 16 of the proposed directive on goods and Article 17 of the proposal on supply of digital content set out a seller's right to pursue remedies against earlier links in the contractual chain in the case of liability to the consumer (right of redress). Nonetheless, "( $t$ )he person against whom the seller may pursue remedies and the relevant actions and conditions of exercise, shall be determined by national law."

The proposed directives briefly note that it is for the Member States to make sure that "adequate and effective means exist to ensure compliance" with the directives. ${ }^{107}$ Also here, the question arises whether this issue, and concrete consequences for market actors in the case of not complying with the directives, should be regulated in more detail to achieve fully-harmonized practical effects in Member States. ${ }^{108}$

The issues noted above are likely to result in a situation where "fully harmonized" rules would not necessarily guarantee uniform or even highly similar practices or case outcomes in different Member States. ${ }^{109}$ On the one hand, divergence as regards the application and practical significance of EU law(-based) rules is likely, especially if preliminary ruling requests for interpretation of EU law are not presented to the CJEU. On the other hand, at some point preliminary ruling requests will emerge, and intervention will take place alongside de facto further harmonization by the most authoritative interpreter of EU law. This intervention may be significant and intense. ${ }^{110}$

In addition to remaining divergence between the rules applicable in each Member State, adopting the proposed directives might also signify coherence issues within Member State systems, as suggested by Lehmann, for example. ${ }^{111}$ In particular, the proposed rules on the consequences of termination and restitution as well as on damages liability intervene relatively far in these traditionally very national areas of law, but as individual, specific "spikes" of EU law, which still rely significantly on complementing national law.

Moreover, the directive proposals concern the online (and other distance) sales environment. The separation of online/offline regimes as a result of new rules focusing on the online context in particular, as well as the pointillist nature of the 
proposed rules, may cause disruption and incoherence both as regards EU law and Member State systems, as underlined by commentators. ${ }^{112}$ Hence, it should be noted, for instance, that consumers, businesses, lawyers and courts could continue to suffer problems related to several sets and types of applicable rules, and face legal uncertainty. At the national level it might also be challenging to recognize which parts of legislation or which particular details should be interpreted in accordance with EU law methods, noting, inter alia, the indirect effect of directives, and taking into account the constantly developing case law of the CJEU. ${ }^{113}$

It is also possible to pose the academic question whether, in the sphere of online sales and distribution, the law on transactions should be harmonized more globally instead of focusing on EU harmonization. ${ }^{114}$ Online shopping by European customers is not limited to European or EU suppliers. Hence, in order to achieve a more comprehensive boost for online shopping - or more solid consumer confidence developing law at a more global level would be desirable (even though of course highly challenging).

\section{The Proposed Consumer Contract Rules and Interfaces with Other Matters}

To continue about the distinction between online and offline sales and the regimes covering them, the goals of the proposed directives may be undermined by any such separation. For instance, companies may see particular rules for online sales as requiring separate sets of standard terms, and as discouraging in terms of their first attempt in the online distribution mode. This may be strongly felt by small and medium-sized companies in particular. Matters like these may hinder the growth of e-commerce and lessen consumer choice compared to what it could be. Moreover, separate regimes with differing rights clearly might cause further consumer confusion and insecurity.

Nonetheless, the Commission does not seem particularly concerned about the online/offline issue. It hints that the contemplated general revision of EU consumer law might even out the differences between the regimes. ${ }^{115}$ Moreover, the Commission suggests that companies may use the most consumer-friendly terms in all their sales, thus making a set of terms applicable to all types of transactions. ${ }^{116}$ Prima facie, it seems that businesses should study this option with care. The future final formulations of online sales rules are relatively central to a decision.

As regards the bigger picture and themes not included in the scope of the proposed consumer contract directives, the proposals do not tackle such matters as copyright issues, data protection and special features of the sharing economy and platforms. Nevertheless, other DSM initiatives may alleviate this issue once, or if, the initiatives lead to concrete action. However, dealing for instance with different aspects of unjustified geo-blocking, especially as regards interfaces with competition concerns and copyright matters, is still in progress or only starting.

With respect to portability of digital content, succeeding in enacting legislation at a relatively quick pace is notable. However, it should be pointed out that the new Regulation addresses a relatively marginal issue relevant in the context of digital content distribution. Moreover, the proposed regulation was criticized as partially 
vague and, for example, for not even properly defining how a temporary visit to another country was to be understood, even though the issue is central to this legislation. Moreover, tracking users of content in terms of their visits to other countries (and for deciding whether they make visits or begin more permanent stays) may be seen as constituting privacy issues. Other EU bodies drafted suggestions for amendments in the proposed regulation, but even after those the instrument remains partially ambiguous and non-exhaustive as well as possibly challenging to fit together with existing regimes and practices. Dealing with portability matters happens at the intricate interface between copyright, licensing, contracting practices, and other issues. ${ }^{117}$

As regards online platforms, the sharing or collaborative economy and related legal relationships, silence in the proposed consumer contract directives may be seen as a notable defect, especially as tackling legal issues related to these themes at the European level does not seem to be taking place otherwise with particular speed. As already noted above, platform-related matters are, according to the Commission, to be studied further and concrete action is still mostly missing. ${ }^{118}$ Furthermore, even though the Commission highlights its "Collaborative Economy Agenda," it is in practice uncertain whether and how soon the European legislator may be expected to actually and concretely tackle the main legal issues in this area and what kind of proposals should be included. ${ }^{119}$

The phenomena of collaborative-economy and platform-based business models are creating novel commercial relationships. These relationships may be "triangular" and difficult to classify from the perspective of traditional consumer and trading law. ${ }^{120}$ For instance, platforms may connect private individuals that act as suppliers and private individuals that act as customers, and it may be unclear who counts as a trader or entrepreneur, to which actors consumer law applies, what kind of actor the platform should be seen as, and who is responsible (and under what kind of criteria) in the case of problems in fulfilling contracts. Current EU consumer or ecommerce law does not resolve these issues exhaustively, and the relevance and practical significance of existing EU law may be obscure. This is true even though, for example, new guidance on unfair commercial practices to some extent touches upon these issues. ${ }^{121}$

Needless to say, these matters are highly relevant and have obvious connections to the issue whether the level of consumer protection should be seen as "high" or sufficient.

\subsection{Enforcement, Dispute Resolution and Redress}

The big picture of consumer law enforcement in the EU may be seen as entailing strong reliance on public enforcement by Member State authorities and enforcement by specialized organizations. Practices and procedural details remain significantly national. Private litigation by consumers is rare in the case of breaches of both national and EU consumer law (due, inter alia, to significant costs and risks, and individual claims being small), while cross-border private litigation is made more 
difficult by issues such as jurisdiction and applicable law, language issues, and problems or delays in the enforcement of decisions. The availability and practical significance of class actions ${ }^{122}$ remain dependent on national solutions. The European legislator has been taking steps for increased and more effective consumer law enforcement, by, for instance, encouraging alternative dispute resolution and requiring cooperation from national authorities. ${ }^{123}$

The DSM documents make several references to the need for more efficient enforcement of existing EU law such as consumer and marketing law. ${ }^{124}$ Indeed, the benefits of substantive law - existing or future - are gained only if the law seriously means something in practice. On the one hand, the apparent current challenges in this area might not hold much promise for the DSM project, but, on the other, expressly noting the problem is at least a good sign.

The EU Online Dispute Resolution Platform, highlighted by the Commission in the DSM proposals, functions as a forum for traders and consumers to resolve disputes arising from online purchases. In practice, the Platform functions by channeling disputes to national alternative dispute resolution bodies connected to the platform and that have been selected by the Member States and notified to the Commission. ${ }^{125}$ The platform has been accessible to consumers and traders since 15 February 2016, and may be used for disputes concerning online purchases of goods and services. ${ }^{126}$ At least by the beginning of July 2017, not all the EU Member States or all sectors in every Member State were included in the system. ${ }^{127}$

The benefits and future level of use of the Online Dispute Resolution Platform remain to be seen. Some of the most relevant aspects of its later practical significance include whether consumers are sufficiently aware of the system and whether it is perceived as easy and efficient enough. One might in any case note that, in general, extensive private pursuit of consumer law claims by individuals in any formal systems is not likely, and the relevance of active public enforcement that genuinely works remains high.

Cooperation between national consumer protection enforcement authorities currently encompasses a cooperation framework to allow national authorities from the European Economic Area to jointly address breaches of consumer rules when trader and consumer are established in different countries. The national authorities form a European enforcement network. Cooperation applies to consumer rules covering various areas, such as unfair commercial practices, e-commerce and comparative advertising. The actual action taken within the purview of the Cooperation Regulation (EC) 2006/2004 may include requests for cessation and prohibition of ongoing consumer law infringements as well as exchange of information between national authorities and the Commission. The Cooperation Regulation facilitates exchange of best practices and provides a mutual assistance mechanism. ${ }^{128}$ In any case, it has been noted that the current Regulation and the cooperation it provides for does not effectively address digital markets-related issues. ${ }^{129}$

As regards revising the Cooperation Regulation, the idea is to enhance possibilities to enforce EU consumer law, especially in the digital sphere. The proposed 
improved regulation would "equip enforcement authorities with the powers they need to work together faster and more efficiently." ${ }^{130}$ For example, authorities would be able to request information from domain registrars to detect a trader's identity, carry out mystery shopping to check geographical discrimination (geoblocking) or after-sales conditions, and to order the immediate take-down of websites hosting scams. The Commission would be able to launch and coordinate action to address Union-wide problematic practices. A one-stop-shop approach to consumer law is proposed where enforcement authorities will notify the businesses concerned of issues, asking them to change their practices and, if necessary, to compensate the consumers affected. Consumer protection organizations would be able to signal bad cross-border practices to enforcers and to the Commission. The list of laws to which the cooperation framework applies would be updated. ${ }^{131}$

Revision of the Cooperation Regulation appears promising from the DSM standpoint but its practical effectiveness remains to be seen. Importantly, alertness, efficiency, resources, practices and concrete action taken by cooperating authorities will remain essential as regards the actual impact of cooperation. Furthermore, it may be underlined that even though the Cooperation Regulation with its related framework is already in existence, the DSM documents often note, as observed above, the lack or inefficient enforcement of current consumer-protection and other rules. ${ }^{132}$ Hence, it may be that the issue is not so much about the possibilities or framework for cooperation between authorities, but rather about lack of activity and efficiency in public enforcement more generally. Mere revision of the Cooperation Regulation, or any individual piece of legislation, will not remedy this, and more comprehensive action both at national and EU level would be required.

In any case, the cooperation framework has already, for instance, produced "sweeps" (Commission-coordinated sets of checks carried out simultaneously by national authorities to identify breaches of EU consumer law in a particular sector). These "sweeps" bring to light inappropriate practices or infringements and have also drawn public attention to e-commerce issues. "Sweeps" conducted have concerned, for instance, pre-contractual information available for consumers online, and online comparison tools. ${ }^{133}$ "Sweeps" and prominent reporting on them may also encourage companies to change their practices independently.

In terms of competition issues and potential harm caused to consumers by competition restrictions, it should be noted that from the standpoint of private individuals, competition law enforcement and possibilities to obtain redress for harm caused by anticompetitive practices remain notably separate from consumer law enforcement in the EU. This is equally relevant for physical goods e-commerce and digital content distribution. Competition issues and the position of consumers are also discussed below in Section 5.4.

One striking aspect of the DSM materials is repeated reference to the need for more effective enforcement of consumer-protection or related rules, and notes regarding, for instance, enhancing consumer protection cooperation and use of the Online Dispute Platform, while elaborate, concrete discussion of these issues is 
conspicuously absent from the DSM documents. ${ }^{134}$ The general development of EU consumer law enforcement supports and will support the DSM initiatives, and the projects should be executed in parallel and in interaction with each other. It would appear that, in any case, a central issue is the primary credibility of EU consumer law and its enforcement, for instance in the form of strict, vigorous public enforcement, so that companies are incentivized to comply with the law even to start with. It is crucial for DSM goals that the online environment is not seen as one where breaching the law and escaping enforcement is easy.

Further, regardless of EU efforts, divergences in enforcement across the Union remain a major characteristic of EU consumer-law enforcement. Divergence does not necessarily signify inefficiency. However, divergence may be seen as a problem from the standpoint of a European, uniform, "level-playing-field" DSM. Moreover, divergences in enforcement may blur impressions of consumer protection and affect "consumer confidence."

\subsection{Consumer Confidence}

The DSM documents strongly underline the issue of lack of consumer confidence or trust and, for instance, the positive effect the proposed consumer contract rules will have with respect to this matter. ${ }^{135}$ Nevertheless, the concept of "consumer confidence" and similar expressions is relatively ambiguous. Moreover, the causal relationship between, for example, targeted harmonization of a set of consumer contract rules and a significant improvement in consumer confidence is not selfevident, even if those rules concern key rights and obligations.

According to the legislative proposals and other materials published by the European legislator, a central factor in lack of consumer confidence is insecurity about contractual rights in cross-border e-commerce. ${ }^{136}$ Lack of consumer confidence or trust could itself be seen as referring to unwillingness to make purchases online with cross-border sellers because of fears concerning, for example, misunderstandings, the other party's compliance with the contract, and dealing with problem situations. Moreover, discussions on lack of consumer confidence note or presuppose that, without fears like these, consumers would find cross-border online transactions tempting because, for instance, of the broader selection of products and services available. ${ }^{137}$

From this perspective, seeing targeted harmonization of certain consumer contract rules as a solution appears, of course, to some extent well justified. However, matters other than ignorance of or insecurity about certain aspects of applicable consumer contract law may also contribute to the current state of (argued) defective consumer confidence. Several matters which the proposed consumer contract rules (or other concrete DSM measures) do not deal with could continue to contribute to consumer confidence problems.

An essential issue is that consumer confidence is at least partially a matter of feelings or beliefs instead of knowledge or common sense. Even some passages in the DSM materials illustrate this, for instance by noting: "Consumers are not con- 
fident when buying online across borders and believe that they are better protected when buying online in their own country, under their familiar domestic law." 138 It should be noted that even though beliefs regarding consumer protection may to some extent be affected by clearer, non-divergent European rules, ${ }^{139}$ these beliefs might not be based on any true information on "better domestic law" even in the first place. It is evident that the domestic law of every Member State cannot be better for consumers than that of other Member States.

Furthermore, the extent to which new EU legislation may change consumer perceptions of their legal position may be affected by matters such as the clarity, comprehensiveness and uniformity of the new European legal regime. The proposed online sales legislation forms targeted harmonization of key aspects of mandatory consumer contract rules. In turn, this signifies that aspects of consumer sales (online and offline) remain governed by other EU law and its national implementing measures as well as by purely national law. ${ }^{140}$ Consumer law enforcement, details of remedies and so on vary from one Member State to another. ${ }^{141}$ Hence, the goal of significantly boosting consumer confidence might not be easily achieved by the contemplated legislation since the whole of consumer law, practical consumer protection, enforcing one's rights and obtaining redress remains complex and possibly difficult to quickly analyze from the standpoint of regular consumers.

Moreover, a major obstacle to increased consumer confidence might be the fact that it is unlikely that consumers actually use extensive amounts of time and energy to explore applicable laws and rights and remedies, but operate based on somewhat vague perceptions - even if the legal framework were to develop by becoming significantly clearer or more beneficial. An improved law may go partially or entirely unnoticed.

A boost to consumer confidence would, in any case, be better achieved if consumers were able to obtain accurate and understandable information on their legal position and rights. A characteristic of the DSM project is layman-friendly communication on developing the legal framework. ${ }^{142}$ Nevertheless, clear information on the whole of the applicable consumer law would be essential too, and should not be forgotten. Moreover, one could remark that practical issues such as the extent to which the media cover legal developments may significantly affect how much relevant information actually reaches consumers. Probably relatively few regular consumers browse even the Commission's basic DSM websites or press releases.

In addition to communication by European and national legislators, traders active in e-commerce and digital content distribution should note their opportunity to alleviate consumer concerns and insecurities by providing appropriate information on their websites. Moreover, consumer law enforcement could further emphasize traders' and service providers' responsibility to communicate on matters relating to the applicable law understandably and accessibly. ${ }^{143}$ 
As regards aspects other than legal that may affect consumer confidence or insecurity, it may be noted that perceptions or feelings about online transactions or digital content service websites are affected by numerous factors.

For instance, websites may only be available in certain languages even though they would in principle be selling to all EU countries. Additionally, where a "less common" language version such as Swedish or Estonian is available, site translations may be of remarkably bad quality. Problems in understanding the language of the sales or service site, or a suspicion that the information available also entails significant translation errors, are prone to discourage consumers from making online purchases or subscriptions. As regards physical goods, expressing for instance the size of clothes and shoes varies from one country to another; moreover, a sales site may use different size markings than actually appear on the product labels themselves. Further, an online store which appears, for example, to be German, may actually ship products from, for instance, China, resulting in additional, noncommunicated customs costs and creating unease about product origins.

As regards digital content services or products, the example of unclear, badlytranslated or foreign-language information on, for instance, requirements for devices, presents yet one more illustration of factors that discourage consumers from international online transactions.

Aspects like these may not fully translate into legal issues as they are also about the business decisions of online traders and not just about complying with some exhaustive regulation on what online sales or service sites should look like, and how they should function and reassure potential customers as to their quality.

As regards platforms and related matters, the Commission documents note that consumers' ability to place their trust, for instance, in reviews or price comparisons is central for the functioning of markets and consumer welfare, and that these elements should be unbiased and trustworthy. One aspect of promoting this would be, again, enhanced enforcement of existing marketing and consumer law rules. ${ }^{144}$

As the DSM materials seem at least partially to imply that consumer confidence or trust is not an independent goal in itself but a tool for achieving growth, ${ }^{145}$ the Commission's discussions on the theme should probably be read in this light. Nevertheless, no matter how consumer confidence or trust is understood, it is apparently not, regardless of the rhetoric, being tackled in a very detailed, systematic, comprehensive or in-depth manner in the DSM documents.

\subsection{Functioning Competition and Consumers}

As regards dealing with competition concerns under the DSM Strategy, it may be generally noted that this exercise is still in the early stages, even though comprehensive preliminary assessments have been and still are being executed.

In any case, the area of competition in the telecoms sector (and legal issues of roaming and availability of Internet more generally) has developed considerably in 2016-2017. Even though many of the new rules are still at the proposal stage, progress is significant. ${ }^{146}$ 
With respect to the e-commerce sector inquiry, even its final conclusions point to more assessments and investigations being needed to (start to) remedy competition concerns. Partially, the findings of the inquiry may be said to be rather obvious, for instance, as regards how the online environment changes competition and introduces new concerns. However, the discussion in the final report as well as in the related documents is elaborate and forms a solid basis for further action. ${ }^{147}$

Similarly, as regards platforms, what has been done is to map out key issues and areas for future action and enforcement activity, although tackling platform-related legal issues and competition concerns are still at a preliminary stage. ${ }^{148}$

With respect to geo-blocking, progress with the legislative proposal is of course welcome. However, it should be noted that the proposed legislation does not exhaustively eliminate potential competition concerns. In any case, clearly indicating practices that are at least illegal (anticompetitive or not) creates predictability. ${ }^{149}$ The conclusions of the e-commerce sector inquiry include the (perhaps unsurprising) finding that geo-blocking and licensing practices in digital content distribution are complex issues which should, in the context of competition-law enforcement, be evaluated on a case-by-case basis, also paying attention to potential justifications behind practices that could be seen as restrictions on competition. Distribution of digital content in particular should be analyzed taking into account the specific aspects of the online content business field. ${ }^{150}$ These particular factors include, to cite a simple example, the fact that Europe-wide licenses for copyright-protected content would be expensive, which in turn would be reflected in end-user prices. Furthermore, removing geo-blocking in digital content distribution would not necessarily change the markets tremendously, as content supplied and demanded depends on cultural and linguistic factors, buying power, and also, for example, on how advanced devices are commonly used in different regions. ${ }^{151}$

In any case, current Commission activity in e-commerce competition law enforcement and the trend of opening new investigations in the wake of a sector inquiry is good news for European consumers. Public enforcement proceedings will take time, but they may bring significant benefits to consumers in the form of better-functioning competition. It should be noted, however, that Commission investigations opened - or even Commission decisions closing those investigations and finding infringements - may only constitute the first steps in proceedings that may also involve years of further litigation and appeals before the EU Courts. As regards authoritative interpretations of EU competition law in the context of digital markets and related novel issues, the CJEU is the only actor whose guidance actually cements the correct reading of the law. Uncertainty as regards interpreting competition law in the online environment may thus continue for a long time.

At the same time, the Commission's visible interest in digital markets and online distribution may encourage companies to change possibly problematic practices without intervention by the authorities. However, the threat here is that they are also beginning to abstain from efficient and beneficial practices which would not actually harm consumers or societal welfare or infringe competition provisions. 
This risk is high, in particular if the significance and correct interpretation of EU competition law is obscure, as unfortunately is the case with many online business model issues.

It may also be noted that the impact of the "Single Market imperative," which relates to eliminating market segmentation along national borders, may at points make applying and interpreting competition law more complex, due to the partially separate goals pursued. This signifies that EU-level guidance (case law or soft law) on correct interpretations and solutions is highly valuable. ${ }^{152}$

The position of consumers in the enforcement of EU competition law, and consumer possibilities to obtain compensation for harm they have suffered due to competition restrictions, is not elaborately discussed in the DSM materials. Regardless of earlier efforts by the European legislator ${ }^{153}$ and some prominent preliminary rulings by the CJEU, ${ }^{154}$ the fact is that it is rarely reasonable for consumers to pursue private competition law-based claims against companies. This is even more so where competition issues in the online business environment are concerned, as correct interpretations of EU competition provisions may be highly uncertain. ${ }^{155}$ Furthermore, as noted in the context of consumer-law enforcement, possibilities for and efficiency of collective redress still depend on choices made in each Member State. ${ }^{156}$

Moreover, the concrete impact that consumer wishes or requests may have on public enforcement efforts by the Commission or national competition authorities may be limited. ${ }^{157}$ Nevertheless, public enforcement carried out by the authorities on their own initiative benefits consumers in any case. While private litigation and collective actions still suffer from significant hurdles and intricacies in the EU, the established public enforcement system is the most efficient way of actually catching and terminating competition-distorting practices.

\section{Concluding Remarks}

This contribution has discussed the EU's DSM Strategy, with the main focus on implications for consumers. The article has analyzed how the consumer-related aims of the DSM are discussed in official documents, and mirrored expressed aims as well as concerns with concrete proposals and action taken regarding e-commerce and digital markets, in particular, by the Commission. The analysis has focused on different aspects of online sales of goods and digital content distribution, functioning competition, as well as on enforcement and redress with respect to consumer and competition law.

It has been noted that some of the consumer-related goals set for the DSM agenda and visible in the rhetoric of the Commission in particular seem to be still relatively far away. Moreover, official materials related to the DSM project do not seem to tackle some of the issues that would appear central on the basis of "rhetoric of aims," at least on a detailed, in-depth level. 
Additionally, a particular aspect of the online environment is that the digital world creates new possibilities for consumption and for recognizing and tempting potential customers. Novel markets are emerging, both real and imaginary (that is, of the virtual world). Research is still ongoing into new aspects of consumer behavior and consumer desires. This also holds true with respect to new "actor roles" in the digital environment and the decreasing significance of the traditional clear-cut dichotomy between traders and consumers. ${ }^{158}$ To a notable extent, it remains to be seen how the legal framework should be developed in order to catch up with new behaviors and transaction practices, along with emerging concerns. For example, the use of consumer or user data for commercial purposes - a matter not extensively discussed in this study - constitutes a concrete area that calls for analysis and development of the legal framework. The same applies to the increasingly blurred roles of consumers/users, suppliers/providers/creators and intermediaries, along with matters relating to the rights and obligations of each party. ${ }^{159}$

Although DSM Strategy materials make general references to, for instance, empowering or protecting consumers, nevertheless they mostly focus on the "traditional consumer role" and relatively traditional legal aspects of consumer protection. In any case, the need for assessment and legal development has been recognized, for instance in the area of use of consumer/user data. Moreover, DSM materials refer to issues concerning social media, the sharing economy, and new "actor roles" as areas requiring analysis and action. ${ }^{160}$ Nevertheless, the status quo remains that elaborate and concrete proposals, or even discussion, are largely absent as regards developing the legal framework in this respect. ${ }^{161}$

Analytical comments and findings regarding different aspects or fields of the DSM Strategy and the position of consumers have already been made above. The following brief remarks in this Section are merely a selective summary and synthesis.

The proposed directives concerning consumer contract rules for online sales of goods and supply of digital content seem to suffer from many potential problems and partially appear to fail to meet the goals set for them. It may be noted, for instance, that the proposed directives seem to entail many elements similar to those once criticized in the context of the (unsuccessful) Consumer Rights Directive Proposal of 2008. ${ }^{162}$ Moreover, the distinction between rules of online (and other distance) sales and offline sales may be seen as a problematic and complexityincreasing trend, even though it would probably be partially temporary.

The new Regulation on portability may be mentioned as an example of true progress in terms of the DSM, and this has been highlighted by the European legislator accordingly. (It also, conveniently, constitutes a theme where the benefits of the DSM may be easily explained to consumers or laymen.) ${ }^{163}$ Nevertheless, the Regulation represents an attempt at tackling a marginal aspect of the entire field of copyright, licensing and geo-blocking issues, and even this limited piece of legislation has been heavily criticized during the drafting process. Unsurprisingly, these 
are matters which are not much in evidence on the basis of the DSM materials and press releases.

The DSM materials repeatedly note the need for more efficient, more active enforcement of both existing and future rules, and plans are in place to increase consumer-law enforcement and facilitate dispute resolution. However, discussions on these matters are somewhat vague in the DSM materials. In any case, it is interesting that existing legal frameworks combined with more effective and active enforcement could actually resolve some of the issues emphasized as part of the DSM project.

Competition concerns constitute an example of an area where extensive assessments have now been carried out but focused action is still partially at the planning stage only. Evidently, the DSM is not yet a unified, European-wide Single Market where conditions of functioning and fair competition would prevail. Moreover, some of the conclusions drawn so far regarding dealing with novel problems in digital markets are still rather vague, thus underlining that further work is needed. At any rate, public competition-law enforcement concerning online business models is clearly increasing, which is a good sign for consumers and with respect to the future of digital markets. This should be seen as highly positive, even though the possibilities for consumers to obtain compensation for potential harm suffered due to competition restrictions are not optimal.

Digital content distribution constitutes a phenomenon which from a legal standpoint touches upon (at least) consumer protection, competition, copyright and licensing, all intertwined. It is noteworthy that many relevant issues are still significantly unresolved, and merely noted as future areas for assessment and action. This is true even though DSM sub-projects such as the e-commerce sector inquiry and legislative proposal concerning geo-blocking may initially have seemed initiatives that would tackle these matters in a concrete manner and soon.

To conclude, it may be noted that facilitating e-commerce and growth as well as increasing consumer confidence or consumer trust in online transactions are clearly visible as express goals of the DSM project. Nevertheless, improving the position and confidence or trust of consumers appears most central as a means for more growth. Regardless of the consumer-focused rhetoric of the Commission in particular, detailed considerations on consumer confidence or relating to improving the position of consumers are partially absent from the legislative proposals and other materials. To some extent, empowering consumers and boosting consumer confidence appears vague, general rhetoric which is not entirely meant to be mirrored by any detailed proposals and comprehensive analyses of relevant factors. ${ }^{164}$ 


\section{NOTES AND REFERENCES}

1. Commission, "Digital single market - Bringing down barriers to unlock online opportunities," https://ec.europa.eu/commission/priorities/digital-single-market_en (accessed 9 July 2017).

2. Commission, "A Digital Single Market Strategy for Europe" (Communication) $\operatorname{COM}(2015) 192$ final, p. 3.

3. Ibid., p. 4. See also Commission, "Digital Contracts for Europe" (Communication) $\operatorname{COM}(2015) 633$ final (hereinafter "Digital Contracts Communication $\operatorname{COM}(2015) 633$ final").

4. Commission, "Digital Single Market: EU negotiators agree on new rules allowing Europeans to travel and enjoy online content services across borders" (Press release, 7 February 2017) IP/17/225.

5. See, e.g., Commission, "A Digital Single Market Strategy for Europe" (Communication) COM(2015) 192 final, Annex: "Roadmap for completing the Digital Single Market."

6. E.g., for personal data protection a draft regulation on ePrivacy was published in January 2017 (Commission, "Proposal for a Regulation on the protection of individuals with regard to the processing of personal data by the Union institutions, bodies, offices and agencies and on the free movement of such data, and repealing Regulation (EC) No 45/2001 and Decision No 1247/2002/EC" COM(2017) 8 final). With respect to an initiative regarding European free-flow data and a European Cloud, the Commission launched two consultations in January 2017 that would run until April (http://ec.europa.eu/growth/toolsdatabases/newsroom/cf/itemdetail.cfm?item_id=9048; https://ec.europa.eu/digital-singlemarket/en/news/public-consultation-building-european-data-economy, both accessed 9 July 2017). A preliminary report following a sector inquiry into e-commerce was published on 15 September 2016 (Commission, "Preliminary Report on the E-commerce Sector Inquiry" (Staff Working Document) SWD(2016) 312 final), with the final report published first 10 May 2017 (Commission, "Final Report on the E-commerce Sector Inquiry" COM(2017) 229 final). See also n. 40 regarding platforms.

7. See Digital Contracts Communication COM(2015) 633 final; Commission, "Proposal for a directive on certain aspects concerning contracts for the online and other distance sales of goods" $\operatorname{COM}(2015) 635$ final (hereinafter "Proposed Directive on Online Sales of Goods COM(2015) 635 final"); Commission, "Proposal for a directive on certain aspects concerning contracts for the supply of digital content" $\operatorname{COM}(2015) 634$ final (hereinafter "Proposed Directive on Supply of Digital Content COM(2015) 634 final"); Commission, "Impact Assessment - Accompanying the document Proposals for Directives (1) on certain aspects concerning contracts for the supply of digital content and (2) on certain aspects concerning contracts for the online and other distance sales of goods" (Staff Working Document) SWD(2015) 274 final/2, replacing SWD(2015) 274 final (hereinafter "Impact Assessment SWD(2015) 274 final/2").

8. Digital Contracts Communication $\operatorname{COM}(2015) 633$ final, pp. 3-5; Proposed Directive on Online Sales of Goods COM(2015) 635 final, pp. 2-3; Proposed Directive on Supply of Digital Content COM(2015) 634 final, pp. 2-3; Impact Assessment SWD(2015) 274 final/2, pp. 10-11, 13-16.

9. See Digital Contracts Communication $\operatorname{COM}(2015) 633$ final, p. 3.

10. Digital Contracts Communication $\operatorname{COM}(2015) 633$ final, pp. 3, 5-6; Proposed Directive on Online Sales of Goods COM(2015) 635 final, pp. 3, 5-6; Proposed Directive on Supply of Digital Content COM(2015) 634 final, pp. 3, 11-13, 19-22. 
11. Directive (EC) $1999 / 44$ on certain aspects of the sale of consumer goods and associated guarantees [1999] OJ L 171/12.

12. Digital Contracts Communication $\operatorname{COM}(2015) 633$ final, pp. 2-5. See also Impact Assessment SWD(2015) 274 final/2, pp. 40-42, 49, 114-116, 122-123.

13. See, e.g., Digital Contracts Communication $\operatorname{COM}(2015) 633$ final, pp. 2, 4, 6-7, 9; Proposed Directive on Online Sales of Goods COM(2015) 635 final, pp. 6, 11, 18, 22; Proposed Directive on Supply of Digital Content COM(2015) 634 final, pp. 16, 18. See also similarly Commission, "A comprehensive approach to stimulating cross-border eCommerce for Europe's citizens and businesses" (Communication) COM(2016) 320 final (hereinafter "Stimulating E-Commerce Communication COM(2016) 320 final"); Commission, "Commission proposes new e-commerce rules to help consumers and companies reap full benefit of Single Market" (Press release, 25 May 2016) IP/16/1887.

14. Digital Contracts Communication $\operatorname{COM(2015)~} 633$ final, pp. 2, 5; Impact Assessment SWD(2015) 274 final/2, pp. 76-80, 85.

15. Digital Contracts Communication $\operatorname{COM(2015)~} 633$ final, p. 3; Proposed Directive on Online Sales of Goods COM(2015) 635 final, pp. 3-6; Impact Assessment SWD(2015) 274 final/2, pp. 7-8; Directive (EC) 1999/44.

16. During the period of reversed burden of proof, it is for the trader to prove that no defect that would signify non-conformity existed at the time of delivery.

17. See Proposed Directive on Online Sales of Goods COM(2015) 635 final, pp. 3-6.

18. Digital Contracts Communication $\operatorname{COM}(2015) 633$ final, p. 4.

19. See Digital Contracts Communication COM(2015) 633 final, p. 4; Proposed Directive on Online Sales of Goods COM(2015) 635 final, p. 13; Impact Assessment $\operatorname{SWD}(2015) 274$ final/2, p. 75.

20. See Directive (EU) 2011/83 on consumer rights, amending Council Directive 93/13/EEC and Directive 1999/44/EC and repealing Council Directive 85/577/EEC and Directive 97/7/EC [2011] OJ L 304/64.

21. See Directive (EC) 2000/31 on certain legal aspects of information society services, in particular electronic commerce, in the Internal Market [2000] OJ L 178/1.

22. See Directive (EEC) 93/13 on unfair terms in consumer contracts [1993] OJ L 95/29.

23. Proposed Directive on Online Sales of Goods COM(2015) 635 final, pp. 2-6; Impact Assessment SWD(2015) 274 final/2, pp. 6, 22.

24. Proposed Directive on Online Sales of Goods COM(2015) 635 final, p. 5. The other DSM initiatives relevant for e-commerce in physical goods will be discussed in the following Sections.

25. Commission, "Review of EU Consumer law (Fitness Check)," http://ec.europa.eu/ consumers/consumer_rights/review/index_en.htm (accessed 9 July 2017).

26. See e.g. Digital Contracts Communication $\operatorname{COM(2015)~} 633$ final, p. 8; Impact Assessment SWD(2015) 274 final/2, page 6.

27. Proposed Directive on Online Sales of Goods COM(2015) 635 final, see p. 14 and the proposed Article 1.

28. Ibid., see also pp. 14-15.

29. Ibid., see also p. 15.

30. Ibid., see also pp. 15-16.

31. Ibid., see also p. 16.

32. Commission, "Online Platforms and the Digital Single Market Opportunities and Challenges for Europe" (Communication) $\operatorname{COM(2016)~} 288$ final (hereinafter "Platforms Communication $\operatorname{COM}(2016) 288$ final"); Commission, "Online Platforms - Accompanying 
the document Communication on Online Platforms and the Digital Single Market" (Staff Working Document) SWD(2016) 172 (hereinafter "Platforms SWD(2016) 172"); Commission, "Digital Single Market - Online Platforms," https://ec.europa.eu/digital-singlemarket/en/policies/online-platforms (accessed 9 July 2017).

33. Commission, "Proposal for a Regulation on cross-border parcel delivery services" $\operatorname{COM}(2016) 285$ final; Commission, "Parcel delivery in the EU," https://ec.europa.eu/ growth/sectors/postal-services/parcel-delivery_en (accessed 9 July 2017).

34. Regulation (EU) 524/2013 on online dispute resolution for consumer disputes and amending Regulation (EC) No 2006/2004 and Directive 2009/22/EC [2013] OJ L 165/1; Directive (EU) 2013/11 on alternative dispute resolution for consumer disputes and amending Regulation (EC) No 2006/2004 and Directive 2009/22/EC [2013] OJ L 165/63. See also Commission, "Solving disputes online: New platform for consumers and traders" (Press release, 15 February 2016) IP/16/297.

35. Regulation (EC) 2006/2004 on cooperation between national authorities responsible for the enforcement of consumer protection laws [2004] OJ L 364/1.

36. Proposed Directive on Online Sales of Goods COM(2015) 635 final, p. 5.

37. Proposed Directive on Online Sales of Goods COM(2015) 635 final, p. 5. Enforcement cooperation will in the future cover the proposed directive.

38. Directive (EC) 2005/29 concerning unfair business-to-consumer commercial practices in the internal market and amending Council Directive 84/450/EEC, Directives 97/7/EC, 98/27/EC and 2002/65/EC of the European Parliament and of the Council and Regulation (EC) No 2006/2004 ("Unfair Commercial Practices Directive") [2005] OJ L 149/22.

39. Commission, "Guidance on the Implementation/Application of Directive 2005/29/EC on Unfair Commercial Practices - Accompanying the Communication. A comprehensive approach to stimulating cross-border e-Commerce for Europe's citizens and businesses" (Staff Working Document) SWD(2016) 163 final (hereinafter "Guidance on the Unfair Commercial Practices Directive SWD(2016) 163 final").

40. Platforms Communication $\operatorname{COM(2016)~} 288$ final; Platforms SWD(2016) 172. The Communication formulates the Commission's policy approach to platforms and identifies areas for future action or assessment. See also Commission, "Commission updates EU audiovisual rules and presents targeted approach to online platforms" (Press release, 25 May 2016) IP/16/1873; Commission, "Commission publishes mid-term review of the 2015 Digital Single Market strategy" (Fact Sheet, 10 May 2017) MEMO/17/1233; Commission, "Digital Single Market - Online Platforms," https://ec.europa.eu/digital-single-market/en/ policies/online-platforms (accessed 9 July 2017). E.g. the mid-term review notes platforms as a key emerging challenge.

41. E.g., Impact Assessment SWD(2015) 274 final/2, pp. 4-5, 13-15; Proposed Directive on Supply of Digital Content COM(2015) 634 final, pp. 2-3; Digital Contracts Communication COM(2015) 633 final, pages 2-5.

42. Proposed Directive on Supply of Digital Content COM(2015) 634 final, pp. 2-3; Impact Assessment SWD(2015) 274 final/2, 13-16.

43. Proposed Directive on Supply of Digital Content COM(2015) 634 final, pp. 3-4.

44. Ibid., p. 4.

45. Ibid., p. 4.

46. See, e.g., Commission, "A Digital Single Market Strategy for Europe" (Communication) $\operatorname{COM(2015)~} 192$ final, p. 7; Commission, "Proposal for a Regulation on ensuring the cross-border portability of online content services in the internal market" 
COM(2015) 627 final (hereinafter "Proposed Regulation on Portability COM(2015) 627 final").

47. Proposed Directive on Supply of Digital Content COM(2015) 634 final, p. 12.

48. Ibid., see also pp. 12-13.

49. Proposed Regulation on Portability COM(2015) 627 final.

50. Commission, "Digital Single Market: EU negotiators agree on new rules allowing Europeans to travel and enjoy online content services across borders" (Press release, 7 February 2017) IP/17/225; Regulation (EU) 2017/1128 on cross-border portability of online content services in the internal market OJ L 168/1.

51. Guidance on the Unfair Commercial Practices Directive SWD(2016) 163.

52. E.g. Commission, "A Digital Single Market Strategy for Europe" (Communication) $\operatorname{COM}(2015) 192$ final, pp. 3-4, 9-10; Commission, "Commission decision initiating an inquiry into the e-commerce sector pursuant to Article 17 of Council Regulation (EC) No 1/2003" (HT.4607, 6. May 2015) C(2015) 3026 final; Commission, "Antitrust: Commission launches e-commerce sector inquiry" (Press release, 6 May 2015) IP/15/4921. See also Commissioner Margrethe Vestager, "Competition policy for the Digital Single Market: Focus on e-commerce" (Bundeskartellamt International Conference on Competition, Berlin, 26 March 2015), http://europa.eu/rapid/press-release_SPEECH-15-4704_en.htm (accessed 9 July 2017).

53. E.g. Commission, "A Digital Single Market Strategy for Europe" (Communication) $\operatorname{COM}(2015) 192$ final, pp. 6, 9-12.

54. See, e.g., Commission, "Final Report on the E-commerce Sector Inquiry" COM(2017) 229 final, paras 38, 24-27; Commission, "Staff Working Document Accompanying the document Final report on the E-commerce Sector Inquiry" (Staff Working Document) SWD(2017) 154 final (hereinafter "Sector Inquiry SWD(2017) 154 final"), paras 167-177, 499-514.

55. See Commission, "Final Report on the E-commerce Sector Inquiry" COM(2017) 229 final, paras 11-15; Sector Inquiry SWD(2017) 154 final, paras 116-126, 147-157, 602-608, 965-966.

56. See, e.g., Case C-74/14 Eturas and Others v Lietuvos Respublikos konkurencijos taryba [2016] EU:C:2016:42 where a technical modification by a travel booking platform operator was used to cap discounts of competing traders selling via the same platform. See also Commission, "Final Report on the E-commerce Sector Inquiry" COM(2017) 229 final, para. 13; Sector Inquiry SWD(2017) 154 final, para. 149.

57. Commission, "Final Report on the E-commerce Sector Inquiry" COM(2017) 229 final, paras 54-56; Sector Inquiry SWD(2017) 154 final, paras 648-651.

58. See, e.g., Commission, "Towards a modern, more European copyright framework" (Communication) $\operatorname{COM}(2015) 626$ final, pp. 3-6; Commission, "A Digital Single Market Strategy for Europe - Analysis and Evidence, Accompanying the document Communication from the Commission to the European Parliament, the Council, the European Economic and Social Committee and the Committee of the Regions, A Digital Single Market Strategy for Europe" (Staff Working Document) SWD(2015) 100 final (hereinafter "DSM SWD(2015) 100 final"), p. 23; Benoît Keane, "The Application of EU Competition Law in the Sports and Entertainment Sectors 2014/2015" (2015) 6 Journal of European Competition Law \& Practice 735, 735-737; Juha Vesala, "Geo-Blocking Requirements in Online Distribution of Copyright-Protected Content: Implications of Copyright Issues on Application of EU Antitrust Law" forthcoming in [2017] 25 Michigan State International Law Journal. 
59. See further, e.g., Lars. Kjølbye, Alessio Aresu, and Sophia Stephanou, "The Commission's E-Commerce Sector Inquiry: Analysis of Legal Issues and Suggested Practical Approach" [2015] 6 Journal of European Competition Law \& Practice 465; Rupprecht Podszun, "The Digital Economy: Three Chances for Competition Law" [2016] 23 Maastricht Journal of European and Comparative Law 747; Miguel De la Mano and Alison Jones, "Vertical Agreements under EU Competition Law: Proposals for Pushing Article 101 Analysis, and the Modernization Process, to a Logical Conclusion" (2017) King's College London Law School Research Paper No. 23 (Working Paper, SSRN) https: //papers.ssrn.com/sol3/papers.cfm?abstract_id=2930943 (accessed 9 July) forthcoming in D. Healey and M. Jacbos (eds.), Handbook of Research Methods of Competition Law (Edward Elgar); Katri Havu, "The Digital Single Market and E-commerce: Some Remarks concerning Online Sales and Distribution from the Private Enforcement Point of View" [2016] 9 Global Competition Litigation Review 50.

60. See further, e.g., Kjølbye, Aresu and Stephanou (n. 59).

61. Case C-74/14 Eturas and Others v Lietuvos Respublikos konkurencijos taryba [2016] EU:C:2016:42. Issues potentially relevant on the basis of the facts but outside the scope of the preliminary ruling included defining the relationship between travel agencies and the online platform and the concept of a competition-restricting vertical agreement. See further, e.g., Katri Havu and Neža Zupančič, "Case Comment: Collusion and Online Platforms in Eturas" [2016] 11 The Competition Law Review 225.

62. Regulation (EU) 330/2010 on the application of Article 101(3) of the Treaty on the Functioning of the European Union to categories of vertical agreements and concerted practices, OJ 2010 L 102/1.

63. Case C-230/16 Coty Germany v Parfümerie Akzente.

64. See further, e.g., Ariel Ezrachi, "The Ripple Effects of Online Marketplace Bans" [2017] 40 World Competition 47; Pablo Ibanez Colomo, "Case C-230/16, Coty: a straightforward issue with major implications" (Chillin'Competition, 16 February 2017), https:// chillingcompetition.com/2017/02/16/case-c-23016-coty-a-straightforward-issue-withmajor-implications/ (accessed 9 July 2017).

65. See also e.g. Ezrachi (n. 64); Stefan Wartinger and Lukas Solek, "Restrictions of Third-Party Platforms within Selective Distribution Systems" [2016] 39 World Competition 291.

66. See for further discussion e.g. Podszun (n. 59); Kjølbye, Aresu and Stephanou (n. 59) 474-476; Vasiliki Brisimi, The Interface between Competition and the Internal Market: Market Separation under Article 102 TFEU (Hart 2014) 37-112; Havu (n. 59).

67. Commission, "A Digital Single Market Strategy for Europe" (Communication) $\operatorname{COM(2015)} 192$ final, p. 6; DSM SWD(2015) 100 final, p. 24; Commission, "Antitrust: Commission launches e-commerce sector inquiry" (Press release, 6 May 2015) IP/15/4921.

68. Commission, "A Digital Single Market Strategy for Europe" (Communication) $\operatorname{COM}(2015) 192$ final, p. 6.

69. Ibid., pp. 9, 11-12.

70. Ibid., pp. 9-10.

71. Commission, "Proposal for a Regulation on addressing geo-blocking and other forms of discrimination based on customers' nationality, place of residence or place of establishment within the internal market and amending Regulation (EC) No 2006/2004 and Directive 2009/22/EC" COM(2016) 289 final (hereinafter "Proposed Geo-Blocking Regulation $\operatorname{COM(2016)} 289$ final"). 
72. See e.g. European Parliament, "E-commerce: ending unjustified geo-blocking across the EU" (Press release, 25 April 2017), 20170425IPR72324.

73. See Proposed Geo-Blocking Regulation COM(2016) 289 final; Stimulating ECommerce Communication COM(2016) 320 final, pp. 4-6; Commission, "Geo-Blocking", https://ec.europa.eu/digital-single-market/en/policies/Geo-Blocking (accessed 9 July 2017).

74. The final, agreed text of the legislative proposal was not available at the moment of writing this contribution (by 9 July 2017). See Proposed Geo-Blocking Regulation $\operatorname{COM}(2016) 289$ final, recital 29, article 4(1)(b). See also Stimulating E-Commerce Communication $\operatorname{COM}(2016) 320$ final, pp. 4-7; European Parliament, "E-commerce: ending unjustified geo-blocking across the EU" (Press release, 25 April 2017) 20170425IPR72324.

75. Commission, "Final Report on the E-commerce Sector Inquiry" COM(2017) 229 final.

76. See ibid., paras 23-75; Sector Inquiry SWD(2017) 154 final, paras 165-192, 342354, 652-654, 975-1008, 1024-1033.

77. See Commission, "Antitrust: Commission publishes final report on e-commerce sector inquiry” (Press release, 10 May 2017) IP/17/1261.

78. Commission, "Antitrust: Commission opens three investigations into suspected anticompetitive practices in e-commerce" (Press release, 2 February 2017) IP/17/201; Focus Home (Case COMP/AT.40413); Koch Media (Case COMP/AT.40414); ZeniMax (Case COMP/AT.40420); Bandai Namco (Case COMP/AT.40422); Capcom (Case COMP/ AT.40424); Holiday (Case COMP/AT.40181); Pioneer (Case COMP/AT.40182).

79. Commission, "Antitrust: Commission opens formal investigations into Nike's, Sanrio's and Universal Studios' licensing and distribution practices" (Press release, 14 June 2017) IP/17/1646; Licensed merchandise - Nike (Case COMP/AT.40436) Opening of Proceedings; Licensed merchandise - Universal Studios (Case COMP/AT.40433 Opening of Proceedings; Licensed merchandise - Sanrio (Case COMP/AT.40432) Opening of Proceedings.

80. Commission, "Antitrust: Commission fines Google $€ 2.42$ billion for abusing dominance as search engine by giving illegal advantage to own comparison shopping service" (Press release, 27 June 2017) IP/17/1784; Google Search (Shopping) (Case COMP/ AT.39740).

81. See n. 40 above.

82. Platforms Communication $\operatorname{COM}(2016) 288$ final, pp. 11-13; Platforms SWD(2016) 172, e.g. pp. 12, 14.

83. See Platforms Communication $\operatorname{COM}(2016) 288$ final, p. 13, and updated information: Commission, "Commission publishes mid-term review of the 2015 Digital Single Market strategy" (Fact Sheet, 10 May 2017) MEMO/17/1233; Commission, "Digital Single Market - Online Platforms," https://ec.europa.eu/digital-single-market/en/policies/onlineplatforms (accessed 9 July 2017).

84. See further e.g. Ariel Ezrachi, "The Competitive Effects of Parity Clauses on Online Commerce" [2015] 11 European Competition Journal 488.

85. Commission, "Antitrust: Commission accepts commitments from Amazon on ebooks" (Press release, 4 May 2017) IP/17/1223; E-book MFNs and related matters (Amazon) (Case COMP/AT.40153) Commission Decision C(2017) 2876 final [2017] Final commitments.

86. See, e.g., Commission, "Digital Single Market - Telecom Laws," https://ec.europa. eu/digital-single-market/en/policies/telecom-laws (accessed 9 July 2017); Commission, "End of roaming charges: EU negotiators agreed on wholesale prices, the final piece to 
make it happen" (Press release, 1 February 2017) IP/17/193; Regulation (EU) 2016/2286 on laying down detailed rules on the application of fair use policy and on the methodology for assessing the sustainability of the abolition of retail roaming surcharges and on the application to be submitted by a roaming provider for the purposes of that assessment, OJ L 344/46; Commission, "Proposal for a Directive establishing the European Electronic Communications Code (Recast)" $\operatorname{COM}(2016) 590$ final/2; Commission, "Evaluation of the regulatory framework for electronic communications" SWD(2016) 313 final; Commission, "Connectivity for a Competitive Digital Single Market - Towards a European Gigabit Society" (Communication) COM(2016) 587 final; Commission, "5G for Europe: An Action Plan" COM(2016) 588 final; Commission, "Proposal for a Regulation amending Regulations (EU) 1316/2013 and (EU) 283/2014 as regards promoting Internet connectivity in local communities, COM/2016/0589 final.

87. See Proposed Directive on Supply of Digital Content COM(2015) 634 final, pages 6-7; Proposed Directive on Online Sales of Goods COM(2015) 635 final, pp. 7-8; Impact Assessment SWD(2015) 274 final/2, pp. 10-12, 21-22, 40, 45-53.

88. See, e.g., Matthias Lehmann, "A Question of Coherence: The Proposals on EU Contract Rules on Digital Content and Online Sales" [2016] 23 Maastricht Journal of European and Comparative Law 752.

89. See further e.g. Sacha Prechal, Directives in EC Law (2nd edn, Oxford University Press 2005), 92-96, 131-134, 253-270; Jan Smits, "Full Harmonization of Consumer Law? A Critique of the Draft Directive on Consumer Rights" [2010] 18 European Review of Private Law, 5, 8-10; Christian Twigg-Flesner, "Introduction: EU Consumer and Contract Law at a Crossroads?" in Christian Twigg-Flesner (ed.), Research Handbook on EU Consumer and Contract Law (Edward Elgar 2016), 1, 4-9; Fryderyk Zoll, "The Problems Associated with the Implementation of Directives into National Legal Systems - A Few Examples from the Codified Legal Traditions," in the same volume, 68, 72-74; Angus Johnston and Hannes Unberath, "European Private Law by Directives: Approach and Challenges" in Christian Twigg-Flesner (ed.), Cambridge Companion to European Union Private Law (Cambridge 2010), 85, 86-87; Jan Smits, "Convergence of Private Law in Europe: Towards a New Ius Commune?" in Esin Örücü and David Nelken (eds), Comparative Law, A Handbook (Hart 2007), 219, 224-225; Jules Stuyck, "The Court of Justice and the Unfair Commercial Practices Directive" [2015] 52 Common Market Law Review, 721, 721-722, 749-752. Additionally, more general, critical discussions on the desirability and feasibility of European harmonization concerning core areas of private law should be noted: see, e.g., Thomas Wilhelmsson, "Europeiseringen av privaträtten: För ett fragmenterat utbyte av erfarenheter" [2001] 114 Tidsskrift for Rettsvitenskap 1; Smits 2010 (this n.); Ola Zetterquist, "E Pluribus Unum? A Constitutional Perspective on the Pluralism and the Unity of European Private Law," in Annina Persson and Eleonor Kristoffersson (eds.), Swedish Perspectives on Private Law Europeanisation (Hart 2017), 175.

90. See Commission, "Consumer Policy Strategy 2002-2006" (Communication) $\operatorname{COM}(2002) 208$ final; Commission, "A more coherent European contract law - An action plan" (Communication) COM(2003) 68 final. For discussion, see e.g. Hans-W. Micklitz, "Minimum/Maximum Harmonisation and the Internal Market Clause," in Geraint Howells, Hans-W. Micklitz and Thomas Wilhelmsson (eds.), European Fair Trading Law, The Unfair Commercial Practices Directive (Routledge 2006), 27, 28-30; Guido Comparato, Hans-W. Micklitz, and Yane Svetiev, "The Regulatory Character of European Private Law" in Christian Twigg-Flesner (ed.), Research Handbook on EU Consumer and Contract Law 
(Edward Elgar 2016), 35, 59-60; Hugh Beale, “The Story of EU Contract Law - from 2001 to 2014," in the same volume, 431, 432-438.

91. Commission, "Proposal for a Directive of the European Parliament and of the Council on Consumer Rights" COM(2008) 614 final.

92. See further e.g. Micklitz and Svetiev (n. 90) 59-60; Twigg-Flesner (n. 89) 4-5; Smits 2010 (n. 89); Willem Van Boom, "The Draft Directive on Consumer Rights: Choices Made and Arguments Used" [2009] 5 Journal of Contemporary European Research, 452.

93. Directive (EU) 2011/83.

94. See e.g. the Unfair Commercial Practices Directive (EC) 2005/29.

95. Even though by now we have also seen the rise and the fall of a proposal for a general Common European Sales Law, see Commission, "Proposal for a Regulation on a Common European Sales Law" COM(2011) 635 final.

96. See Digital Contracts Communication $\operatorname{COM}(2015) 633$ final, p. 2; Proposed Directive on Online Sales of Goods COM(2015) 635 final, p. 2; Proposed Directive on Supply of Digital Content COM(2015) 634 final, p. 2; Impact Assessment SWD(2015) 274 final/2, pp. 4-5. See further similarly e.g. Platforms Communication COM(2016) 288 final, pp. 24, 15; Stimulating E-Commerce Communication $\operatorname{COM}(2016) 320$ final, pp. 2-5, 11; Commission, "Commission publishes mid-term review of the 2015 Digital Single Market strategy" (Fact Sheet, 10 May 2017) MEMO/17/1233. For discussion see, e.g. Lehmann (n. 88) 755-756; Twigg-Flesner (n. 89) 7-9. For more general analysis regarding the relationship between Internal Market goals and consumer protection in EU law, see e.g. Hannes Unberath and Angus Johnston, "The Double-headed Approach of the ECJ Concerning Consumer Protection" [2007] 44 Common Market Law Review 1237.

97. See further e.g. Esther Arroyo Amayuelas, "The Idea of an Optional Contract Code," in Christian Twigg-Flesner (ed.), Research Handbook on EU Consumer and Contract Law (Edward Elgar 2016), 463, 485-486; Van Boom (n. 92) 455-459; Smits 2010 (n. 89).

98. Proposed Directive on Online Sales of Goods COM(2015) 635 final, pp. 7-8; Proposed Directive on Supply of Digital Content COM(2015) 634 final, pp. 6-7; Impact Assessment SWD(2015) 274 final/2, pp. 21-22, 29.

99. See further e.g. Michele Graziadei, "Fostering a European Legal Identity Through Contract and Consumer Law" in Christian Twigg-Flesner (ed.), Research Handbook on EU Consumer and Contract Law (Edward Elgar 2016), 82, 99; Smits 2010 (n. 89) 10-11.

100. Proposed Directive on Online Sales of Goods COM(2015) 635 final, pp. 7, 12; Proposed Directive on Supply of Digital Content COM(2015) 634 final, pp. 9-10; Impact Assessment SWD(2015) 274 final/2.

101. Platforms Communication $\operatorname{COM(2016)~} 288$ final, pp. 4-5; Platforms SWD(2016) 172, pp. 46-47; Commission, "Digital Single Market - Online Platforms", https://ec. europa.eu/digital-single-market/en/policies/online-platforms (accessed 9 July 2017).

102. Article 1, Proposed Directive on Online Sales of Goods COM(2015) 635 final; Article 3, Proposed Directive on Supply of Digital Content COM(2015) 634 final (see also recital 10).

103. Articles 4-14, Proposed Directive on Online Sales of Goods COM(2015) 635 final; Articles 6-16, Proposed Directive on Supply of Digital Content COM(2015) 634 final.

104. Article 13, Proposed Directive on Online Sales of Goods COM(2015) 635 final (see also Article 1 regarding Member State laws); Article 13, Proposed Directive on Supply of Digital Content COM(2015) 634 final (see also Article 3 and recital 10 regarding Member State laws). 
105. On its part, recital 43 of the proposed directive on digital content highlights that digital content is not subject to wear and tear and may be supplied over a longer period. "It is, therefore, justified not to provide a period during which the supplier should be held liable for any lack of conformity which exists at the time of the supply of the digital content. Consequently Member States should refrain from maintaining or introducing such a period." However, "Member States should remain free to rely on national prescription rules in order to ensure legal certainty in relation to claims based on the lack of conformity of digital content." Proposed Directive on Supply of Digital Content COM(2015) 634 final.

106. Article 14(1), Proposed Directive on Supply of Digital Content COM(2015) 634 final reads "The supplier shall be liable to the consumer for any economic damage to the digital environment of the consumer caused by a lack of conformity with the contract or a failure to supply the digital content. Damages shall put the consumer as nearly as possible into the position in which the consumer would have been if the digital content had been duly supplied and been in conformity with the contract."

107. Article 18, Proposed Directive on Supply of Digital Content COM(2015) 634 final; Article 17, Proposed Directive on Online Sales of Goods COM(2015) 635 final.

108. See also, e.g., discussion by Alberto De Franceschi, "The EU Digital Single Market Strategy in Light of the Consumer Rights Directive: The 'Button Solution' for Internet Cost Traps and the Need for a More Systematic Approach" [2015] 4 Journal of European Consumer and Market Law 144.

109. See also e.g. Lehmann (n. 88) 764-770, 774; De Franceschi (n. 95), and similarly regarding EU law on unfair contract terms Peter Rott, "Unfair Contract Terms," in Christian Twigg-Flesner (ed.), Research Handbook on EU Consumer and Contract Law (EE 2016), 287, 312-313.

110. See also e.g. Smits 2010 (n. 89), 9-10; Lehmann (n. 88) 768-769, and similarly regarding withdrawal rights Jonathon Watson, "Withdrawal Rights," in Christian TwiggFlesner (ed.), Research Handbook on EU Consumer and Contract Law (Edward Elgar 2016), 241, 245-250.

111. Lehmann (n. 88) 765-766.

112. See further e.g., Lehmann (n. 88); Twigg-Flesner (n. 89) 7-9.

113. See also Lehmann (n. 88) 765-770, 774.

114. See also, e.g., Lars Gorton, "Global Business: National Law, EU Law and International Customs and Contracts" in Annina Persson and Eleonor Kristoffersson (eds.), Swedish Perspectives on Private Law Europeanisation (Hart 2017), 115, 119-120, 124, 153-154.

115. Proposed Directive on Online Sales of Goods COM(2015) 635 final, pp. 9, 12-13; Impact Assessment SWD(2015) 274 final/2, pp. 6-7, 23-28, 40-45, 51, 73-74.

116. Proposed Directive on Online Sales of Goods COM(2015) 635 final, pp. 12-13; Impact Assessment SWD(2015) 274 final/2, pp. 6-7, 23-28, 40-45, 73-74. The approach itself may be criticized due to its nature as "legislation through the back door," that is, because of indirectly pursuing harmonization of more than just the online sales rules, if this is the correct interpretation of the Commission's explanations. See for discussion e.g. Lehmann (n. 88), 764-766, 774.

117. See Proposed Regulation on Portability COM(2015) 627 final; Regulation (EU) $2017 / 1128$ on cross-border portability of online content services in the internal market, OJ L 168/1. For discussion and overview, see e.g. Juliane Althoff, "EU Council's Approach to Cross-Border Portability of Online Content Services" [2016] 27 Entertainment Law Review 269; Gianluca Campus, "Recent developments on the EU Proposal for a Regulation on 
cross-border portability” (Kluwer Copyright Blog, 19 December 2016), http://kluwercopy rightblog.com/2016/12/19/recent-developments-eu-proposal-regulation-cross-borderportability/ (accessed 9 July 2017); "Agreement reached on EU portability regulation" (Osborne Clarke, 8 February 2017), http://www.osborneclarke.com/insights/agreementreached-on-eu-portability-regulation/ (accessed 9 July 2017).

118. See n. 40.

119. See e.g. Platforms Communication $\operatorname{COM}(2016) 288$ final, pp. 4-5; Commission, "A European Agenda for the Collaborative Economy" (Communication) COM(2016) 356 final; Commission, "Collaborative Economy," http://ec.europa.eu/growth/single-market/ services/collaborative-economy_en (accessed 9 July 2017).

120. See, e.g., Platforms Communication COM(2016) 288 final, pp. 4-5. See also, e.g., Christoph Busch, Hans Schulte-Nölke, Aneta Wiewiórowska-Domagalska, and Fryderyk Zoll, "The Rise of the Platform Economy: A New Challenge for EU Consumer Law?" [2016] 5 Journal of European Consumer and Market Law 3; Lehmann (n. 88), 758.

121. See further e.g., Platforms Communication COM(2016) 288 final, pp. 4-5; Commission, "Guidance on the Unfair Commercial Practices Directive" (Staff Working Document) SWD(2016) 163 final; Stimulating E-Commerce Communication COM(2016) 320 final, pp. 5, 10-11. See for discussion, e.g., Busch et al. (n. 120); Christiane Wendehorst, "Platform Intermediary Services and Duties under the E-Commerce Directive and the Consumer Rights Directive" [2016] 5 Journal of European Consumer and Market Law 30; Vassilis Hatzopoulos and Sofia Roma, "Caring for Sharing? The Collaborative Economy under EU Law" [2017] 54 Common Market Law Review 81.

122. See Commission, "Recommendation on common principles for injunctive and compensatory collective redress mechanisms in the Member States concerning violations of rights granted under Union Law" [2013] OJ L 201/60.

123. See further e.g. Norbert Reich, "Legal Protection of Individual and Collective Consumer Interests" in Norbert Reich, Hans-W. Micklitz, Peter Rott and Klaus Tonner, European Consumer Law (2nd edn, Intersentia, 2014), 339; Norbert Reich "Cross-Border Consumer Protection," in the same volume, 285; Geraint Howells, "Consumer Law Enforcement and Access to Justice," in Christian Twigg-Flesner (ed.), Research Handbook on EU Consumer and Contract Law (Edward Elgar 2016), 406.

124. See, e.g., Commission, "A Digital Single Market Strategy for Europe" (Communication) COM(2015) 192 final, p. 5; Impact Assessment SWD(2015) 274 final/2, pp. 17, 35; Stimulating E-Commerce Communication $\operatorname{COM}(2016) 320$ final, pp. 2-4, 9; Commission, "Commission proposes new e-commerce rules to help consumers and companies reap full benefit of Single Market" (Press release, 25 May 2016) IP/16/1887; Platforms Communication $\operatorname{COM}(2016) 288$ final, pp. 5, 10-11; Platforms SWD(2016) 172 (e.g. pp. 12, 14, 21 which note that existing legal rules should already tackle issues such as marketing and transparency).

125. See Regulation (EU) 524/2013 on online dispute resolution for consumer disputes and amending Regulation (EC) No 2006/2004 and Directive 2009/22/EC, OJ L 165/1; Regulation (EU) 2015/1051 on the modalities for the exercise of the functions of the online dispute resolution platform, on the modalities of the electronic complaint form and on the modalities of the cooperation between contact points provided for in Regulation (EU) No 524/2013 of the European Parliament and of the Council on online dispute resolution for consumer disputes, OJ L 171/1; Commission, "Solving disputes online: New platform for consumers and traders" (Press release, 15 February 2016) IP/16/297. 
126. Online Dispute Resolution, https://ec.europa.eu/consumers/odr/main/?event=main. about.show (accessed 9 July 2017); Commission, "Buying online and solving disputes online: 24.000 consumers used new European platform in first year" (Press release, 24 March 2017) IP/17/727.

127. "Dispute resolution bodies are currently not available on this site for some sectors and in the following countries: Romania, Spain." (Online Dispute Resolution, "Disclaimer", https://ec.europa.eu/consumers/odr/main/?event=main.home.show (accessed 9 July 2017)).

128. See Consumer Protection Regulation (EC) 2006/2004. See also, e.g., Commission, "Impact Assessment accompanying the document Proposal for a Regulation of the European Parliament and of the Council on cooperation between national authorities responsible for the enforcement of consumer protection laws" (Staff Working Document) SWD(2016) 164 final, p. 7. See also Commission, "Cross-border enforcement and cooperation (CPC)," http: //ec.europa.eu/consumers/enforcement/cross-border_enforcement_cooperation/index_en.htm (accessed 9 July 2017).

129. See, e.g., Stimulating E-Commerce Communication COM(2016) 320 final, pp. 5, 9: Commission, "Cross-border enforcement and cooperation (CPC)," http://ec.europa.eu/ consumers/enforcement/cross-border_enforcement_cooperation/index_en.htm (accessed 9 July 2017).

130. See Commission, "Cross-border enforcement and cooperation (CPC)," http://ec. europa.eu/consumers/enforcement/cross-border_enforcement_cooperation/index_en.htm (accessed 9 July 2017).

131. Commission, "Proposal for a Regulation on cooperation between national authorities responsible for the enforcement of consumer protection laws" $\operatorname{COM}(2016) 283$ final, pp. 3-4, 9, 15; Commission, Consumer Protection Cooperation Network, http://ec.europa. eu/internal_market/scoreboard/performance_by_governance_tool/consumer_protection_co operation_network/index_en.htm (accessed 9 July 2017).

132. See n. 124.

133. E.g., Commission, Consumer Protection Cooperation Network, http://ec.europa.eu/ internal_market/scoreboard/performance_by_governance_tool/consumer_protection_coope ration_network/index_en.htm (accessed 9 July 2017).

134. See, e.g., Commission, "A Digital Single Market Strategy for Europe” (Communication) COM(2015) 192 final, p. 5; Impact Assessment SWD(2015) 274 final/2, pages 17, 45; Platforms Communication $\operatorname{COM(2016)~} 288$ final, pp. 5, 10-11. See also Platforms $\operatorname{SWD}(2016) 172$, e.g. pp. 12, 14, 21 which note that existing legal rules should already tackle issues such as marketing and transparency.

135. See, e.g., Commission, "A Digital Single Market Strategy for Europe” (Communication) $\operatorname{COM(2015)~} 192$ final, pp. 4-5, 13; nn. 12-13, 41.

136. See, e.g., nn. 12-13, 41.

137. See, e.g., Digital Contracts Communication COM(2015) 633 final, pp. 2, 4, 6-7; Proposed Directive on Online Sales of Goods COM(2015) 635 final, pp. 2-3, 10-11, 19; Proposed Directive on Supply of Digital Content COM(2015) 634 final, pp. 1, 6, 10, (and recitals 27, 44); Impact Assessment SWD(2015) 274 final/2, pp. 13-15; Stimulating ECommerce Communication $\operatorname{COM}(2016) 320$ final, pp. 2-5; Commission, "Commission proposes new e-commerce rules to help consumers and companies reap full benefit of Single Market" (Press release, 25 May 2016) IP/16/1887.

138. Proposed Directive on Online Sales of Goods COM(2015) 635 final, pp. 2-3. See also Impact Assessment SWD(2015) 274 final/2, pp. 13-14; Commission, "Consumer Conditions Scoreboard - Consumers at home in the Single Market" (2015), http://ec.europa.eu/ 
consumers/consumer_evidence/consumer_scoreboards/11_edition/docs/ccs2015scoreboard _en.pdf (accessed 9 July 2017), pp. 9, 69.

139. See also, e.g., Stimulating E-Commerce Communication $\operatorname{COM(2016)~} 320$ final, p. 5 regarding the impact of new guidance on unfair commercial practices.

140. See also e.g. Proposed Directive on Online Sales of Goods COM(2015) 635 final, pp. 3-6.

141. See also Sections 5.1.-5.2.

142. See, e.g., Commission, "Commission proposes modern digital contract rules to simplify and promote access to digital content and online sales across the EU" (Press release, 9 December 2015) IP/15/6264; Commission, "Digital Single Market: EU negotiators agree on new rules allowing Europeans to travel and enjoy online content services across borders" (Press release, 7 February 2017) IP/17/225; Commission, "Digital Single Market - Portability of online content services" (Fact Sheet, 8 February 2017) MEMO/ 17/243; Commission, "Agreement on Commission's EU data protection reform will boost Digital Single Market" (Press release, 15 December 2015) IP/15/6321.

143. See also Section 5.2. on Enforcement, Dispute Resolution and Redress, and e.g. n. 124 regarding inefficient enforcement of the current rules.

144. Platforms Communication COM(2016) 288 final, pp. 11-13; Platforms SWD(2016) 172, e.g. pp. 12, 14, 21.

145. See, e.g., n. 96.

146. See n. 86.

147. See Commission, "Final Report on the E-commerce Sector Inquiry" COM(2017) 229 final (policy conclusions are presented at paras 73-75), and e.g. the comprehensive Sector Inquiry SWD(2017) 154 final.

148. See n. 40.

149. See Proposed Geo-Blocking Regulation COM(2016) 289 final.

150. Commission, "Final Report on the E-commerce Sector Inquiry" COM(2017) 229 final, paras 16-22, 45-48, 57-72; Sector Inquiry SWD(2017) 154 final, paras 414-433, 1024-1033; Commission, “Antitrust: Commission publishes final report on e-commerce sector inquiry Brussels" (Press release, 10 May 2017) IP/17/1261. See for discussion, e.g., n. 58.

151. Compare to Commission, "A Digital Single Market Strategy for Europe" (Communication) $\operatorname{COM(2015)~} 192$ final, p. 6 ("geo-blocking is a significant cause of consumer dissatisfaction"). See further e.g. Rita Matulionyte, "The Upcoming EU Copyright Review: A Central-Eastern European Perspective" [2015] 46 IIC International Review of Intellectual Property and Competition Law 439.

152. See for further discussion e.g. De la Mano and Jones (n. 59), 11-12, 19-34.

153. Directive (EU) 2014/104 on certain rules governing actions for damages under national law for infringements of the competition law provisions of the Member States and of the European Union [2014] OJ L 349/1.

154. See, e.g., Case C-453/99 Courage v Crehan [2001] EU:C:2001:465; Case C295/04 Manfredi v Lloyd Adriatico Assicurazioni [2006] EU:C:2006:461; Case C-556/12 Kone v ÖBB-Infrastruktur [2014] EU:C:2014:1317.

155. See further, e.g., Havu (n. 59).

156. See Commission, "Recommendation on common principles for injunctive and compensatory collective redress mechanisms in the Member States concerning violations of rights granted under Union Law" [2013] OJ L 201/60. For discussion, see, e.g., Maria 
Ioannidou, Consumer Involvement in Private EU Competition Law Enforcement (Oxford University Press 2015).

157. A complaint or a request for investigation may be filed with the Commission or national competition authorities, but the authorities are not under obligation to start an investigation (see Regulation (EC) No 1/2003 on the implementation of the rules on competition laid down in Articles 81 and 82 of the Treaty [2003] OJ L 1/1, Articles 4-7). See also, e.g., Kati Cseres and Joana Mendes, "Consumers' access to EU competition law procedures: Outer and inner limits" [2014] 51 Common Market Law Review 483.

158. See further e.g. Janice Denegri-Knott and Mike Molesworth, "Concepts and Practices of Digital Virtual Consumption" [2010] 13 Consumption Markets \& Culture 109; Janice Denegri-Knott and Mike Molesworth, "Love it. Buy it. Sell it. Consumer Desire and the Social Drama of eBay" [2010] 10 Journal of Consumer Culture 56; Alladi Venkatesh and Duygu Akdevelioglu, "Social Media Consumer as Digital Avatar," in Margit Keller, Bente Halkier, Terhi-Anna Wilska and Monica Truninger (eds.), Routledge Handbook on Consumption (Routledge 2017), 453, 459-461.

159. See also, e.g., the text accompanying nn. 118-121 above.

160. See, e.g., Commission, "A Digital Single Market Strategy for Europe" (Communication) COM(2015) 192 final, pp. 6-8, 11-12; DSM SWD(2015) 100 final, pp. 4, 52-57; Commission, "Digital Single Market: Two Years on" (2016) https://ec.europa.eu/commission/sites/beta-political/files/2-years-on-dsm_en_0.pdf (accessed 9 July 2017), pp. 5, 11.

161. As regards plans and proposals, or the lack of them, see, e.g., Commission, "MidTerm Review on the Implementation of the Digital Single Market Strategy" (Communication) COM(2017) 228 final; Commission, "Digital Single Market - Online Platforms," https://ec.europa.eu/digital-single-market/en/policies/online-platforms (accessed 9 July 2017); Platforms Communication COM(2016) 288 final; Commission, "Collaborative Economy", http://ec.europa.eu/growth/single-market/services/collaborative-economy_en (accessed 9 July 2017); Commission, "A European Agenda for the Collaborative Economy" (Communication) $\operatorname{COM}(2016) 356$ final.

162. Commission, "Proposal for a Directive of the European Parliament and of the Council on Consumer Rights" COM(2008) 614 final.

163. See Commission, "Commission takes first steps to broaden access to online content and outlines its vision to modernize EU copyright rules" (Press release, 9 December 2015) IP/15/6261; Commission, "Digital Single Market: EU negotiators agree on new rules allowing Europeans to travel and enjoy online content services across borders" (Press release, 7 February 2017) IP/17/225; Council, "Portability of digital services across the EU: Council adopts new rules" (Press release, 8 June 2017) 332/17. A similar strongly underlined success story is the end of roaming charges: see Commission, "End of roaming charges: EU negotiators agreed on wholesale prices, the final piece to make it happen" (Press release, 1 February 2017) IP/17/193.

164. The author wishes to thank research assistants Tone Knapstad and Suvi KurkiSuonio for their invaluable support and Christopher Goddard for language editing. Any errors in the article are those of the author. New materials have been taken into account until 9 July 2017. 